\title{
Do India's activities in Africa liberate and strengthen Africa's position in the Euro-African relation? ${ }^{1}$
}

\author{
Ton Schrijen ${ }^{2}$ \\ University of Groningen, Faculty of Economics and Business \\ Bartjan Pennink ${ }^{3}$ \\ Faculty of Economics and Business \\ University of Groningen
}

\begin{abstract}
This research will analyze the economic relationship between India and Africa by analyzing trade, investments, aid and trade agreements. Moreover, this study will investigate whether there is substitution effect for the economic relationship between Europe and Africa and compare the results to China. The engagements of India appear to be stronger in resource rich countries and prove no substitution effect for the relationship of Europe and Africa. Moreover, India is also behind China in terms of trade. However, while India's engagement might be smaller than China's and Europe's engagement, it might be more beneficial to Africa as the exports provide Africa with a trade surplus, whereas China and Europe do not. Therefore, the trade between India and Africa is a positive development for Africa, especially as Africa manages to reinvest this surplus into the development of its own economy.
\end{abstract}

Keywords: Africa, Sub-Saharan Africa, India, economic relation, trade, investments, development aid, trade agreements, resource driven.

\section{INTRODUCTION}

Over the last decades India has experienced a spectacular economic growth, comparable with the large industrializations as the United Kingdom and United States (Winters \& Yusuf 2007). The trade between India and Africa has also enjoyed impressive growth, many believe that India might offset Europe from its thrown as the largest economic partner of Africa. This article will analyze the economic relationship of India and Europe with Africa, and look at trade, investment, aid and trade agreements. This study adds trade agreements to the conceptual model of Keers \& Pennink (2010) and will analyze the implications of doing so. In addition, what are the consequences for Africa and Europe of the increased engagement by India? Moreover, the case of India will be compared to China, as these countries are often considered equals. This study will finish with recommendations for further research.

\section{Indo-Africa \& European-Africa economic relation in existing literature}

India has been trading with Africa for over one hundred years, and over time it has developed a strong relationship with Africa (Nanji \& Radeva 2009). The economic growth of India over the years, with rates of $8-9 \%$ amplified its role in the global economy (Economist 2007).

\footnotetext{
1 This article is based on the master thesis of Ton Schrijen

2 Ton Schrijen did his master International Business and Management at the University of Groningen, Faculty of Economics and Business.

${ }^{3}$ Bartjan Pennink is Assistant Professor at the Faculty of Economics and Business, University of Groningen
} 
Correspondingly it also increased its engagement with Africa. Broadman (2007) regards the trade and investments between India and Africa to be sustainable as they complement each other with African needs for Indian manufactured goods and India's need for Africa's natural resources. The role of natural resources in this relation is increasing since India wished to diversify its energy needs, due to the possible conflict with its traditional partners Afghanistan and Iraq (Kaplan 2010). While trade between African and India in 1991 was around 967 million dollar, it reached the 35 billion dollar mark in 2008 (Nanji \& Radeva 2009). This is only expected to grow, with estimates going as high as 120 billion by 2012 (McCann 2010). It is important to stress once again the importance of natural resources in the economic relation between India and Africa. The stream of India's investment in Africa is also largely focused on resource rich countries (Broadman 2007; Beri 2010; Pigato 2009; Vidyarthee 2009). Furthermore, it seems that trade and investment policies are often interwoven with development aid, and that aid is often a part of a package deal with Africa (Vidyarthee 2009; Zafar 2007). Europe is the most important trade partner of Africa, in almost all African countries it is the largest exporter or importer (Keers \& Pennink 2010). Moreover, Europe is also the largest partner of Africa in investment and development aid, however the current rise of Indian-Africa engagements, at a much higher pace than Europe, might threaten this position in the long run. Broadman (2007) focuses on the different aspects of trade, investments and aid between Africa, China and India and the opportunities that follow. However, the research also addresses difficulties, such as border formalities that need to be solved in order to further progress trade. The study by Broadman focuses on the growing relationship of China, India and Africa but does not discuss the possible consequences this change might have for other economic partners of Africa. This paper follows upon the study by Keers and Pennink (2010) on the effects of the Sino-African relation. It investigates whether Indian- African endeavors might negatively affect the European-African relation, and whether Indian trade, investments and development aid will become a preferred substitute for European engagements. Furthermore, it is discussed whether this possible effect is different for African oil-exporters and oil-importers since academics often point to the importance of natural resources in the engagements of India.

\section{Theoretical model for the study on the relation between India and Africa}

This paragraph will deal with the research design, the conceptual model, and the factors and data-set used in this study to answer the following research question:

Is the growing economic relationship between India and Africa a substitute for the traditional relationship between Africa and Europe?"

\section{Theoretical model}

The research by Broadman (2007) on behalf of the World Bank that analyzes trade, foreign direct investments and formal trade policies between countries and continents led to a surge in research covering the impact and growth of Chinese and India engagements with Sub-Saharan Africa. The framework of Broadman was the foundation for further investigation. Zafar (2007) investigated the economic relation of China with Africa based on trade and investments and elaborated the relation by adding the factor aid into the model, based on the assumption that aid plays an important role in facilitating trade and investments. When analyzing the economic relationship of India with Sub-Saharan Africa several authors indicate the possible differences in results when looking at oil-exporting and oil-importing countries (Pigato 2009; Radelet 2010). 
The research of Keers and Pennink (2010) follows the same line of reasoning used in the aforementioned studies, and analyzes the economic ties between China and Sub-Saharan Africa and whether it might substitute for European-African engagements. This study is a follow up of this research and also analyzes trade, investments, and aid but also adds trade agreements to the model. Trade agreements were part of the initial study by Broadman (2007), where it was one of the policy factors influencing trade and investment patterns. Broadman regards trade agreements as necessity for trade. Moreover, in recent negotiations between Europe and Africa there seems to be controversy over the economic partnership agreements, Meanwhile India is negotiating and changing its trade agreements with various parties. This can be captured in the following conceptual model.

\section{Figure 1: Conceptual model}

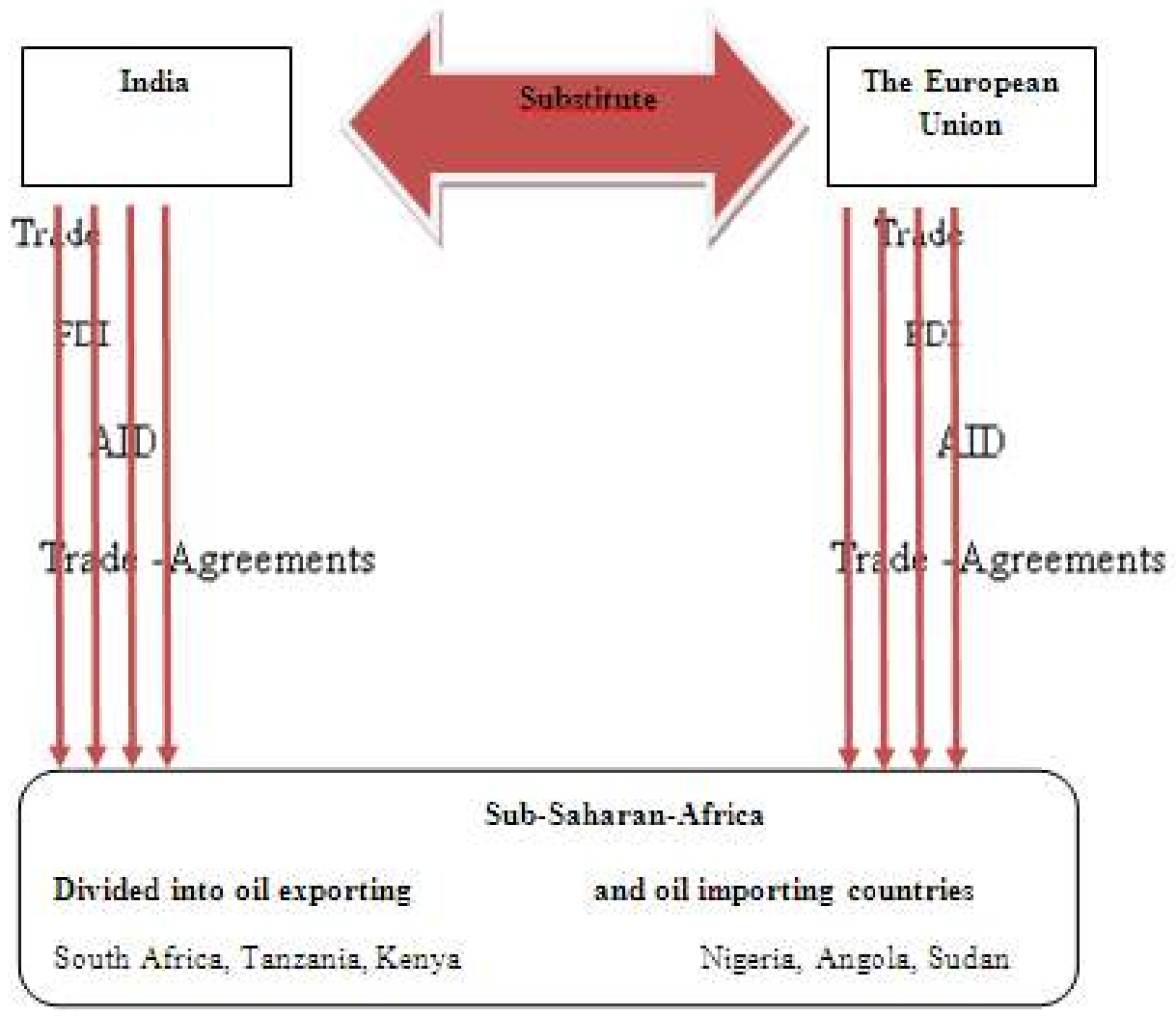

\section{Source: Keers \& Pennink (2010)}

The concepts trade, foreign direct investment, foreign development aid and trade agreements are investigated and together form the economic relationship between India, Europe and SubSaharan Africa.

For analyzing the trade relationship of Sub Saharan Africa with India and Europe, it is necessary to analyze the volume of imports and exports. To investigate whether there is a possible substitution effect it is necessary to examine if Indian-African trade is increasing and if Euro-African trade is simultaneously losing ground. Increasingly there is a notion that NorthSouth trade is losing ground to trade between Southern partners. The economic development in Southern countries has resulted in a growing middle class with more discretionary income; this in turn leads to more demand and opportunities for import and trade.

Second, foreign direct investment (FDI) is an important component in the economic relation. Sauvant (2011) even argues that foreign direct investment has surpassed trade for delivering 
goods and services to foreign markets. In addition, FDI plays a vital role in integrating the production process worldwide. This development became apparent after the large surge of investments sent from developed countries to China and India, which significantly contributed to their impressive growth. In turn these developing countries started their own outward investment schemes (Hattari \& Rajan 2010). Foreign direct investments have increased from 147 billion in 1990 to over 1 trillion in 2004 (UNCTAD 2004). Additionally, developing countries contributed 174 billion, or around 14\% of global outward foreign direct investments. The United Nations mentions that these developing countries invest especially to acquire strategic assets. Therefore, it is expected that resource rich countries are the largest recipients of foreign direct investments, and according to Asiedu (2006) Angola, Nigeria and South Africa indeed were the largest recipients.

According to the Organization for Economic Cooperation and Development (OECD) : "Foreign direct investment reflects the objective of obtaining a lasting interest by a resident entity in one economy (direct investor) in an entity resident in an economy other than that of the investor (direct investment enterprise). The lasting interest implies the existence of a longterm relationship between the direct investor and the enterprise and a significant degree of influence on the management of the enterprise. Direct investment involves both the initial transaction between the two entities and all subsequent capital transactions between them and among affiliated enterprises both incorporate and unincorporated" (OECD Benchmark Definition of Foreign Direct Investment Third Edition 1996). In the Foreign Direct Investment Yearbook of the European Commission, a FDI is considered an international investment when an investor obtains a lasting interest of ten percent or more in an enterprise resident in another country. The research question suggests that Indian FDI will substitute for traditional European investments, and that this effect is stronger in resource rich countries (Hattari \& Rajan 2010). Therefore, this paper will examine whether there are changes in the investments made by India and Europe in the African continent.

Third, the economic factor of development aid is also defined according to the OECD as "The flows of official financing administered with the promotion of economic development and welfare of developing countries as the main objective, concessional in character with a grant element included". Moreover: "official development assistance flows comprise contributions of donor government agencies, at all levels. This also means that besides loans or grants or similar financial flows, it also includes debt cancellation as a form of development aid" (OECD website). The presence of new international actors in Africa and their increased political and economic engagement in Africa influence the context in which development aid takes place (Rampa \& Bilal 2011). Europe urges these countries to join the development assistance committee. Europe wants to involve these nations, hear their views and eventually jointly address development in donor countries (Rampa \& Bilal 2011). While Europe views triangular aid forums in a positive light, Africa and India have different views. Africa now has different sources of development aid, and has the luxury of choosing partners based on its needs, why give up this privilege? Meanwhile India rejects the idea of classifying countries in donors and other as recipients, and therefore does not want to participate in the Western aid effectiveness debates (Rampa \& Bilal 2011).

Several authors (Broadman 2007; Rampa \& Bilal 2011; Vidyarthee 2009) mention the different development models, more specifically the thin line between commerce and aid in the 
engagements of the emerging partners compared to the stricter division made by traditional donors. India approaches Africa as an equal wanting to build a mutually beneficial relationship (Chanana 2009), in addition India as part of the non-aligned movement addresses a noninterference policy. In contrast, traditional donors have always approached Africa from a donor-aid recipient perspective. This relationship is built on philanthropy, but on the condition those developing countries develop western governance principles (Rampa \& Bilal 2011).

The discussion paper of Rampa \& Bilal (2011) gives the following schematic overview capturing the different development approaches between emerging and traditional donors:

Table 5: Different development approach emerging and traditional donors

\begin{tabular}{|c|c|c|}
\hline & Emerging economies & Traditional donors \\
\hline Sector & $\begin{array}{l}\text { Health, agriculture, education, } \\
\text { production, capacities, peace, } \\
\text { security and infrastructure }\end{array}$ & $\begin{array}{l}\text { MDG's, trade liberalization, } \\
\text { promotion of democracy, } \\
\text { human rights and fragile states }\end{array}$ \\
\hline Modalities & $\begin{array}{l}\text { Interest in flexible procedures, } \\
\text { cost efficiency, and speedy } \\
\text { project delivery timeframe }\end{array}$ & $\begin{array}{l}\text { Importance of Paris/Accra } \\
\text { agenda: greater attention to } \\
\text { capacity building, governance } \\
\text { transparency, involvement of } \\
\text { non-state actors and } \\
\text { accountability }\end{array}$ \\
\hline Channels & $\begin{array}{l}\text { Bilateral relations; aid is almost } \\
\text { exclusively disbursed directly } \\
\text { to recipient governments }\end{array}$ & $\begin{array}{l}\text { Regional, pan-African and } \\
\text { multilateral endeavors also } \\
\text { prominent features of their } \\
\text { approach }\end{array}$ \\
\hline
\end{tabular}

Source: Rampa \& Bilal 2011

This schematic overview indicates several important differences. Most importantly it shows that Europe strives for long-term intangible goals while emerging economies such as India attempt clear short-term projects aimed at current needs (Chanana 2009; Zafar 2007). Moreover, the European approach is aimed at the pan-African level, while emerging economies seek partnerships bilaterally. Consequently, these projects are more effective and make it possible to combine them with trade and investments. The new landscape in African aid development has spurred discussion in Europe that development aid is not effective, and that Europe needs to reconsider its policy. Within different European countries changes have been communicated via the press. The Netherlands, for example, has limited the number of countries it supports, and these countries are selected by their strategic importance.

Trade agreements are the fourth and final component of the economic relationship between India, Europe and Africa. Broadman (2007) refers to these as at-the-border-policies, and for this research, the trade agreements that are in effect between the participating countries will be examined. Vidyarthee (2009) describes trade agreements as the level of tariffs and or quotas between two or in some cases several countries. The scope for this paper is not to analyze complete trade agreements, but to see where there are trade agreements in our set of countries. Trade agreements are extensive documents and cover more than just free trade and reducing tariffs. Additionally, trade agreements often include regulatory framework improvements for trade, capital flows, property rights (McQueen 2002). The complex nature of these agreements has led to a shift from a multilateral to a bilateral level to ease negotiations. 
After bilateral agreements are made, these issues are again included in multilateral negotiations (Goodison 2007). Consequently, this could mean that one party has a more powerful influence over the negotiations process, and this might result in unbalanced agreements. Therefore, it is interesting that the process of negotiation between Europe and Africa is at an impasse, while simultaneously countries such as China and India have increased their engagements with Africa. One could argue that Africa feels stronger in this negotiation process because of its decreased dependence on Europe. Moreover, the negotiations between India and Africa take place on a more equal playing field, as India talks about creating a partnership in development.

There are multiple trade agreements in affect for Europe and Africa, and most African countries are usually involved in more than one trade agreement. For example, there is the Cotonou agreement, the everything-but-arms agreement and some countries have also already agreed to new economic partnerships. For India and Africa it is not clear which agreements are already installed as negotiations are still in progress. The later paragraph on trade agreements will discuss the latest updates and implications of African trade agreements and whether Indian engagements are an alternative to the European trade agreements.

\section{African oil exporters vs. African oil importers}

Sub-Saharan Africa consists of 48 countries, and has a rich diversity among its members in terms of history, geography, culture and political systems, which affects their different economic potential (Radelet 2010). Therefore, it is important to look at the characteristics of the individual countries. Pigano (2009) and Radelet (2010) focus on two types of African countries: labor abundant countries and oil- exporters. These types of countries show different growth rates and attract different investments. Radelet (2010) argues that, "the economic dynamics in the oil-exporting countries are fundamentally different from those in other countries in Africa". The world economy is based on oil, gas and other scarce resources that are needed for transport, production, and living. Thus the economic growth in emerging countries will further increase the demand for oil. Further, the availability of oil plays a large role in government policy within these countries and throughout the world. Africa is seen as a key source of oil and gas outside the more politically volatile oil-producing regions in West Asia and the Middle East (Beri 2009). The IMF's list of oil-exporting countries is defined on the basis of net oil-exports and includes Nigeria, Sudan, Angola, Cameroon, Chad, Republic of Congo, Equatorial Guinea, Gabon and Mauritania (IMF). These countries may have profited from the ever increasing oil and commodity prices. From 1996-2008 the average growth rates per capita in the oil exporting countries were higher than in the other African countries (Radelet 2010). It could be the case that the export of oil to India and China plays an important role in these growth figures, and that therefore the result might differ for the group of oilexporters in comparison with oil-importers. Overall, economies blessed with natural resources show different investment and export patterns than those without natural resources. Oil exporting countries tend to rely heavily on extractive industries, while other sectors are relatively underdeveloped. For this reason it is also interesting if we detect different results, or maybe detect a substitution effect only in the oil exporting countries, which confirms the notion of India focusing on energy diversification. The next paragraph will further elaborate how the countries were chosen for the different data sets. 


\section{Countries under investigation}

\section{EMPIRICAL DATA}

The aim of this research is to examine whether the Indian-Africa economic relationship is a substitute and will replace the Euro-African economic relationship. The previous paragraph stressed the differences between oil exporting and oil-importing (labor abundant) countries. Therefore it is necessary to compare these groups. For this study each group will consist of three countries. Publications and research show that India sees Africa as a key source for diversification of its energy needs, it is therefore likely that the data set of oil exporting countries shows a stronger economic relation with India than the data set of oil importing countries (Beri 2010). To test this hypothesis the countries that will be included in the data set of oil importing countries need to be important trade partners of both India and Europe. The European Commission publishes reports of the trade and foreign direct investments for each country, which also state the main trade partner of each country. Based on this data, a search is performed to find the countries suitable for each data set. Notably, all of the countries in the reports have Europe as one of its main import or export partners. The data set of oil-exporting countries consists of Nigeria, Angola and Sudan. While the data set of oil-importing countries consists of South-Africa, Tanzania and Kenya.

Table 6: Data set

\begin{tabular}{|l|l|}
\hline $\begin{array}{l}\text { Oil exporting Sub-Saharan } \\
\text { countries }\end{array}$ & $\begin{array}{l}\text { Oil importing Sub-Saharan } \\
\text { countries }\end{array}$ \\
\hline Nigeria & South Africa \\
\hline Angola & Tanzania \\
\hline Sudan & Kenya \\
\hline
\end{tabular}

The completion of this research is based on the data coming from different international organizations that monitor and publish statistics compiled from their databases. The following institutions are vital for the information gathering process, International Monetary Fund (IMF), World Bank, Eurostat, UNCOM and OECD statistics. Moreover, for gathering the Indian data it is necessary to dive into various Indian government institutions such as the Reserve Bank India (RBI), and the ministries of trade, commerce and finance. The data will be gathered and analyzed for the timeframe 2000-2010 for the selected countries. Hereafter graphs and tables will be compiled to make the data more comprehensive and illustrating.

\section{LIMITATIONS}

This study encountered data availability problems, not all the data on FDI and development assistance is in the public domain. The Indian figures are still very non- transparent, the numbers in this research follow from on other articles and statements. The data on European FDI is not available for al countries, but fortunately, development assistance data is complete. Furthermore, Indian institutes might follow different definitions than European institutes. Finally, the research on Indian engagements in Africa is still very limited, most research is on Chinese engagements. Therefore, this research is valuable in itself that it explores the engagements of India in Africa.

\section{India's Economic Relationship with Sub-Saharan Africa The Role of Natural Resources}

Energy security plays a very important role in India's foreign policy; India is currently fourth on the list of oil consumers worldwide, and the third largest importer (Voll 2010). The Indian economy is projected to grow at 8-9\% annually over the next two decades, leading to a substantial increase in its demand for oil to meet its transportation and production needs (CSIS 2006; Singh 2007). India is very dependent on outside energy supplies, as it is not richly 
endowed with natural resources itself, except for coal (Vidyarthee 2009). Estimates by Beri (2009) a senior research associate at the Institute for Defense Studies, suggest that India can match $25 \%$ of its energy needs internally, and will have to import around $70 \%$ (Singh 2007). China, in comparison, has a higher volume of oil imports, but only imports $46 \%$ of its energy needs (Cheru \& Obi 2011). Therefore, the role of natural resources seems to play a more important role in India's engagement with Africa than China. This illustrates the importance for India to increase its ties with African resource rich countries. Indeed already $18 \%$ of its oil imports come from North and Sub-Saharan Africa (Beri 2010; Voll 2010). At this moment, 65\% of its oil imports originate from the Persian Gulf and India is concerned about its dependence on this politically sensitive region. India is following other major oil importing economies by diversifying its energy sources (Singh 2007). India sees Africa as an attractive source of energy because African oil is of high quality (Beri 2010). Although India has long history of trade links with many Eastern African countries, the need for energy has contributed to the fact that Nigeria has become India's largest partner in terms of import.

\section{India's Trade with Sub-Saharan Africa}

The study by Broadman (2007) already indicated the sustainable nature of the relationship between India and African countries as India's increasing need for natural resources complements Africa's need for manufactured goods. The trade relation of India with SubSaharan African countries has intensified over the entire line, although India imports more than that it exports. Moreover, the graphs confirm the image that energy security plays a vital role in Indians relation with Africa, given that Nigeria and Angola have surpassed South Africa as biggest import partner.

Table 7: Indian imports from Sub-Saharan Africa (millions USD)

\begin{tabular}{|c|c|c|c|c|c|c|c|c|c|c|c|}
\hline & 2000 & 2001 & 2002 & 2003 & 2004 & 2005 & 2006 & 2007 & 2008 & 2009 & 2010 \\
\hline South Africa & 372,4 & 361,9 & 349,7 & 378,0 & 563,4 & 1182,3 & 782,2 & 1350,6 & 2268,7 & 2052,5 & 2916,3 \\
\hline Kenya & 17,9 & 30,1 & 32,3 & 32,9 & 52,4 & 43,7 & 49,5 & 71,8 & 75,1 & 69,4 & 73,3 \\
\hline Tanzania & 98,8 & 82,2 & 64,2 & 95,3 & 112,3 & 111,6 & 94,1 & 134,4 & 178,8 & 227,5 & 220,8 \\
\hline Nigeria & 3918,6 & 2083,1 & 2156,8 & 2391,7 & 50,0 & 60,4 & 4807,6 & 6789,8 & 9175,5 & 5158,9 & 7552,8 \\
\hline Angola & 0,0 & 0,0 & 4,9 & 1,6 & 0,5 & 2,4 & 168,1 & 749,5 & 1117,6 & 3116,5 & 3941,6 \\
\hline Sudan & 7,0 & 7,7 & 19,8 & 79,0 & 27,9 & 30,8 & 22,5 & 16,4 & 510,2 & 344,0 & 440,9 \\
\hline
\end{tabular}

Source: IMF direction of trade statistics

Figure 2: Indian imports from Sub-Saharan Africa (millions USD)

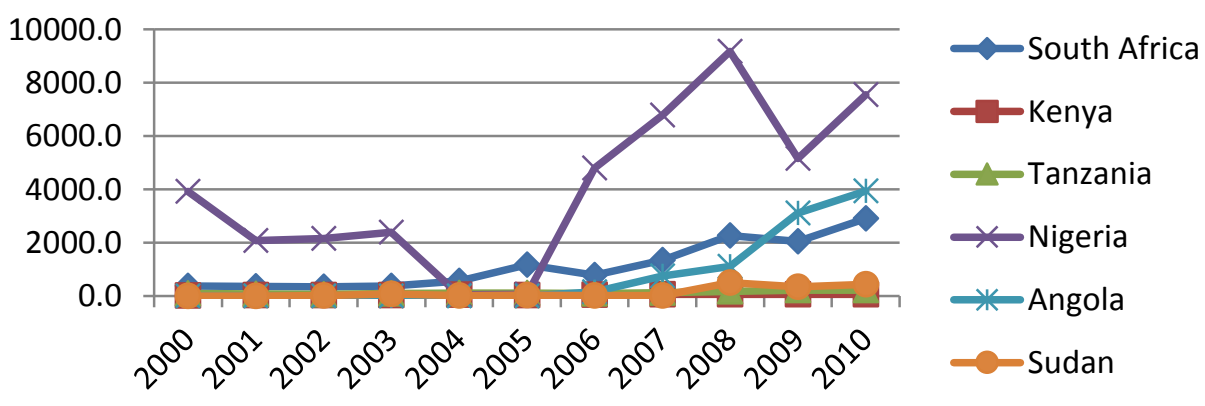


Figure 3: Indian exports to Sub-Saharan Africa (millions USD)

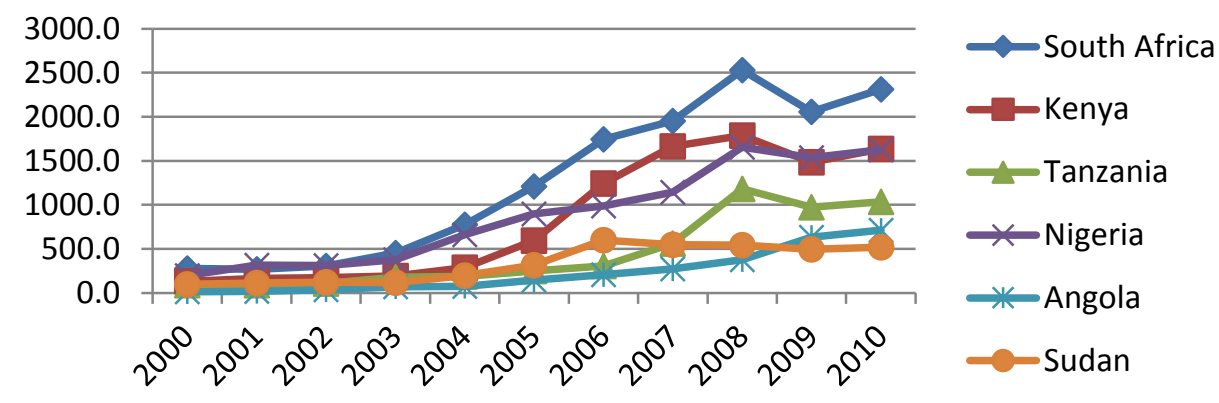

Table 8: Indian exports to Sub-Saharan Africa (millions USD)

\begin{tabular}{|l|r|r|r|r|r|r|r|r|r|r|r|}
\hline & $\mathbf{2 0 0 0}$ & $\mathbf{2 0 0 1}$ & $\mathbf{2 0 0 2}$ & $\mathbf{2 0 0 3}$ & $\mathbf{2 0 0 4}$ & $\mathbf{2 0 0 5}$ & $\mathbf{2 0 0 6}$ & $\mathbf{2 0 0 7}$ & $\mathbf{2 0 0 8}$ & $\mathbf{2 0 0 9}$ & $\mathbf{2 0 1 0}$ \\
\hline South Africa & 278,9 & 269,7 & 307,0 & 454,2 & 773,4 & 1210,4 & 1745,0 & 1954,1 & 2532,6 & 2056,8 & 2312,2 \\
\hline Kenya & 133,1 & 163,3 & 175,4 & 195,1 & 285,8 & 593,0 & 1243,8 & 1664,2 & 1787,2 & 1486,0 & 1634,3 \\
\hline Tanzania & 88,8 & 87,5 & 106,8 & 176,8 & 187,2 & 248,7 & 305,2 & 564,0 & 1182,7 & 975,2 & 1035,7 \\
\hline Nigeria & 199,0 & 315,7 & 309,6 & 377,4 & 661,1 & 898,4 & 985,7 & 1142,2 & 1655,8 & 1536,1 & 1626,2 \\
\hline Angola & 14,1 & 15,5 & 37,7 & 68,5 & 74,8 & 145,2 & 207,1 & 272,4 & 376,6 & 632,5 & 714,2 \\
\hline Sudan & 100,3 & 110,8 & 120,4 & 114,8 & 197,1 & 317,8 & 599,0 & 546,5 & 544,5 & 494,7 & 517,9 \\
\hline
\end{tabular}

Source: IMF direction of trade statistic

\section{India's Foreign Direct Investments in Sub-Saharan Africa}

India's foreign direct investments can be divided into two distinct periods, the period before 1990 and thereafter. After that year the regulations and restrictions on investment were softened for both inward and outward investments. The period before 1990 showed investments in developing countries, while the period after 1990 is characterized by investments in developed countries (Hattaria \& Rajan 2010). They discuss the problems in analyzing Indian FDI data, as the information is not available in the public domain. Other researchers with access to the data find FDI being channeled through offshore financial centers such as Mauritius, but also via the Netherlands. Pradhan (2005) mentions the following reasons for investing abroad: market seeking, technology seeking, brand name seeking, resource seeking and risk diversification seeking. The reasons for investing in Africa are likely to fall under the following categories: market seeking, resource and diversification seeking. As mentioned, India is dependent on oil-imports and wants to diversify its sources of energy. Moreover, the potential of Sub-Saharan Africa as a market is also attractive in the long-run.

\section{India's Development Aid in Sub-Saharan Africa}

Traditionally India is perceived as an important aid receiver (Chanana 2009), and it is even listed in the top 10 of aid recipients (Madote 2010; OECD 2008). Therefore, it is noteworthy that, while being a large recipient of aid, India has its own foreign aid program since the 1950, albeit small, focused on capacity building, and mostly directed to neighboring countries or countries in Africa (McCormick 2008). The scale of its aid programs has increased with its rise in the global economy, although the bulk of aid is still aimed at training, capacity building and other soft investments. According to Chanana (2009) India's aid program annually grew at a $22 \%$ compounded rate over a period of 10 years. India's aspirations on the global scene contribute to its role as a donor. Agrawal (2007) regards this as an attempt to deflect from India's own internal problems and that India wants to put more focus on its new global status as a growing economy. In line with this stature Agrawal (2007) expects India to be a net exporter of development assistance within 5 years.

India development aid is based on capacity building, as it is not able to compete with the hard dollars/euros offered by other African development partners (Chanana 2009; Voll 2010). India 
gives aid through different programs of which the Indian Technological and Economic program (ITEC) is historically the most important. Via this program, India contributes 10.3 million annually, but only $5 \%$ is directed towards Africa, and it is distributed based on the importance for India (Kragelund 2011). As with foreign direct investments, development assistance figures are non-transparent. Neither the Ministry of External Affairs nor the Ministry of Finance maintains records of aid. In 2007, there was an initiative to bundle all development assistance within one agency, however, none of the individual ministries was willing to give up their power (Mitra 2010). Moreover, there is no official definition of what India considers as development assistance. Therefore, this section will at best give an estimate of the development assistance provided by India. The total budget is estimated by Chanana (2010) and it was described in rupees, the Indian currency. The table below is adjusted to dollars. According to McCormick (2008) only 8\% of the total budget in 2004 was allocated to Africa, while most of the development aid budget was directed towards neighboring countries as Bhutan, Afghanistan and Nepal.

Table 9: India's foreign aid development budget 2004-2010 (million USD)

\begin{tabular}{|l|r|r|r|r|r|r|r|}
\hline & $\mathbf{2 0 0 4}$ & $\mathbf{2 0 0 5}$ & $\mathbf{2 0 0 6}$ & $\mathbf{2 0 0 7}$ & $\mathbf{2 0 0 8}$ & $\mathbf{2 0 0 9}$ & $\mathbf{2 0 1 0}$ \\
\hline Grants and loans & 420,3 & 462,4 & 370,3 & 387,9 & 577,9 & 515,5 & 510,4 \\
\hline of which loans & 1,5 & 1,7 & 1,9 & 2 & 1,4 & 1,8 & 1,8 \\
\hline Contributions to I0's & 55 & 71 & 77 & 75,9 & 273,5 & 113,8 & 119,4 \\
\hline Investments in IFIs & 2,2 & 3,9 & 12,4 & 2,9 & 661,5 & 1447,6 & 63,1 \\
\hline $\begin{array}{l}\text { EXIM bank } \\
\text { expenditure }\end{array}$ & 48,5 & 36,7 & 34,3 & 50,3 & 109,1 & 94,1 & 92,1 \\
\hline Total & 526 & 574 & 494 & 517 & 1622 & 2171 & 785 \\
\hline \multicolumn{7}{|c|}{ Source: Chanana (2010) }
\end{tabular}

India's development aid is different from OECD aid in the sense that it is not conditional, but is tied, meaning that the recipient is forced to spend it on products and services of the donor country. All in all, India's development assistance had its peak in 2008-2009 with a budget around 2 billion dollar, before and after it was 0.5 billion dollar. This is in line with literature praising India for its different approach, small scale and its focus on capacity building. Additionally, a recent article discusses Indian aid and mentions the aid budget for Africa to have increased from 22.5 million dollar 2004 to 24.6 million dollar in 2009. It has also written off debt under the HIPC II initiative of Tanzania, Mozambique, Uganda and Zambia. Most of the development assistance is part of the Focus Africa program of India. Voll (2010) mentions the following initiatives, pan -African E- Network including Tele-medicine and distant learning linked to Indian universities at a total cost of 1 billion dollar. An overview of alternative assistance by India is given below.

- India-Africa summit: "India pledges to provide 500 million dollar in concessional credit facilities to West -African states in 2008"

- "India pledges 180 million dollar to improve water supply and ten million dollar for education in Tanzania, 2011 (Development news 2011)."

- "India offered a credit line of 5 billion dollar to Africa for development, and 700 million dollar for training in 2011, for a period of three years (Development news 2011)."

- "India contributes 900 million dollar for support to Nigeria in 2007 (Earth times 2007)." 
Looking at the estimates by Chanana (2009) it is hard to imagine that all the mentioned projects listed in the media are true, especially since McCormick (2008) mentions that the bulk of foreign aid is directed to Indians neighboring countries.

\section{India's Trade Agreements with Sub-Saharan Africa}

The closed economy of India is slowly opening up to other countries. This process started in the 1990 and aims to liberalize the Indian economy albeit, only under conditions of extreme necessity (India Trade 2010). According to Broadman (2007), trade agreements are a necessity for trade as tariffs protect domestic producers, and out price foreign products making it hard to compete fairly. India is eager to promote trade and is in negotiation with several countries to install free-trade agreements and/or preferential trade agreements.

Similar to the United Nations' Everything but Arms initiative, India has preferential agreements for the least developed countries in Africa. The duty-free tariff preference scheme will cut back tariffs on $85 \%$ of India customs, declining its tariffs by $20 \%$ annually. This agreement focuses on African exports and covers $92.5 \%$ of Africa's exports to India (India commerce 2006). Three countries fall under the least developed countries scheme of India, namely, Tanzania, Angola and Sudan.

South Africa is involved with India and Brazil in a triangular forum that aims to coordinate its political, social and economic interests between the countries internally, but also externally in other international forums (India Commerce 2006). The group aims at starting a free-tradearea but is limited by the presence of both Brazil and South Africa in custom unions, MERCOSUR and SACU respectively (RIS 2006). The negotiations with SACU are still ongoing and this is also the case for Nigeria part of economic community of western African states as well (India Commerce 2006).

\section{Is the Economic Relationship Beneficial Indian perspective}

The African continent is an important strategic partner for India, analyzing trade, investments, aid and the trade agreements confirm this notion. As mentioned, natural resources and then particularly crude oil and natural gas are vital for the Indian economy. This is also confirmed by the stronger growth of trade with resource rich countries. However, as Africa continues to grow economically it also might become a large market for Indian goods. The trade and investments cannot be viewed separately from trade as the aid given by India is tied, and in return, Indian goods and services are bought. Moreover, by increasing its support to Africa, India tries to change its own image, and hopes to gain the support of African nations in its efforts to step up internationally. There are still trade negotiations in process between India and Africa, but the existence of these talks indicate that there is progress.

\section{Sub-Saharan African perspective}

The Sub-Saharan region can benefit from having multiple partners, and it therefore should welcome India's investment, participation in aid, and continue trade negotiations. The large increase in exports to India offers it room to reinvest this additional income. The investments by India and its companies help Africa integrate into the world economy improve their infrastructure, and India's IT expertise could serve Africa well. Moreover, increasing its ties with India make Africa less dependent on Europe, which is still its largest trade partner. India's treatment of Africa as an equal partner points out the paternalistic approach of Europe and gives Africa additional leverage in negotiating with Europe. 


\section{Europe's Economic Relationship with Sub-Saharan Africa European Trade with Sub-Saharan Africa}

Since 2004, the trade between Europe and Sub-Saharan Africa has risen substantially with European imports consistently higher than its exports. The main imports have been energy products, and its main exports were machinery and equipment, however, this trend was ended by the beginning of the financial crisis (Eurostat 2010). The list of Europe's top ten trade partners in Africa shows mainly North- African countries, in which mainly mineral fuels dominate trade. Trade with South Africa shows a more diverse image as it consists of machinery and equipment, manufactured goods and to a lesser percentage mineral fuels. The African Statistical Yearbook names Europe as its main import and export partner. The biggest import partners were France, Germany and Italy. Its main export partners were Italy, France and Spain (ENECA 2010).

Table 10: Top ten trade partners Europe in Africa

\begin{tabular}{|c|c|c|c|c|}
\hline \multicolumn{3}{|c|}{ Extra- EU-27 imports } & \multicolumn{2}{|c|}{ Extra- EU-27 exports } \\
\hline Rank & Country & $\begin{array}{r}\text { Value in } \\
\text { million EUR }\end{array}$ & Country & $\begin{array}{l}\text { Value in } \\
\text { million EUR }\end{array}$ \\
\hline 1 & Libya & 19996 & South Africa & 16040 \\
\hline 2 & Algeria & 17356 & Algeria & 14655 \\
\hline 3 & South Africa & 14928 & Egypt & 12627 \\
\hline 4 & Nigeria & 10453 & Morocco & 11909 \\
\hline 5 & Tunisia & 7891 & Nigeria & 9162 \\
\hline 6 & Morocco & 6510 & Tunisia & 8931 \\
\hline 7 & Egypt & 6112 & Libya & 6471 \\
\hline 8 & Angola & 4916 & Angola & 5471 \\
\hline 9 & Cote d'Ivoire & 3055 & Ghana & 1749 \\
\hline 10 & Cameroon & 1744 & Senegal & 1628 \\
\hline
\end{tabular}

Source: Eurostat

The graphs show an overview of the import and export of Europe with the selection of countries. In the previous research by Keers and Pennink (2008) South African exports were nearly double the exports of Nigeria, while three years later this gap almost disappeared. As mentioned, the financial crisis severely affected the growing trend as the graph shows.

Table 11: European imports from Sub-Saharan Africa 2001-2010 (million USD)

\begin{tabular}{|l|r|r|r|r|r|r|r|r|r|r|}
\hline & $\mathbf{2 0 0 1}$ & $\mathbf{2 0 0 2}$ & $\mathbf{2 0 0 3}$ & $\mathbf{2 0 0 4}$ & $\mathbf{2 0 0 5}$ & $\mathbf{2 0 0 6}$ & $\mathbf{2 0 0 7}$ & $\mathbf{2 0 0 8}$ & $\mathbf{2 0 0 9}$ & $\mathbf{2 0 1 0}$ \\
\hline $\begin{array}{l}\text { South } \\
\text { Africa }\end{array}$ & 8830,2 & 9022,8 & 11300,9 & 14530,7 & 16957,4 & 18521,5 & 21055,6 & 23959,3 & 14575,1 & 21248,9 \\
\hline Kenya & 447,9 & 605,3 & 706,3 & 730,6 & 1054,4 & 1173,0 & 1323,7 & 1519,1 & 1364,4 & 1302,1 \\
\hline Tanzania & 438,2 & 479,6 & 302,9 & 430,8 & 367,6 & 377,7 & 477,5 & 445,3 & 439,4 & 424,6 \\
\hline Nigeria & 4345,2 & 4381,3 & 5257,2 & 5954,6 & 9450,0 & 12399,2 & 12750,5 & 21022,4 & 13285,3 & 17541,1 \\
\hline Angola & 1643,6 & 1929,1 & 1153,3 & 1106,9 & 2966,3 & 2455,0 & 5228,7 & 10435,1 & 6219,9 & 4631,4 \\
\hline Sudan & 213,2 & 183,7 & 319,7 & 169,7 & 131,6 & 80,3 & 183,8 & 163,9 & 130,1 & 109,8 \\
\hline
\end{tabular}




\section{Source: IMF direction of trade statistics}

Figure 4: European imports from Sub-Saharan Africa (millions USD)

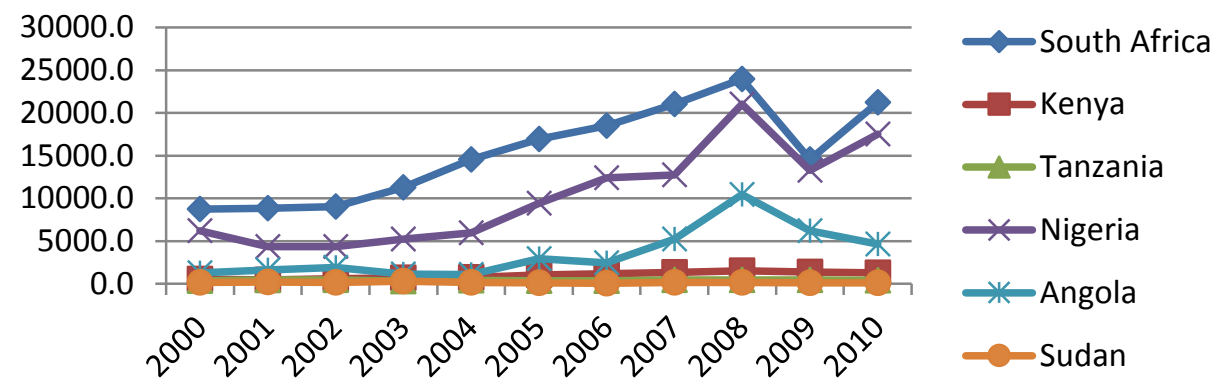

Figure 5: European exports to Sub-Saharan Africa (millions USD)
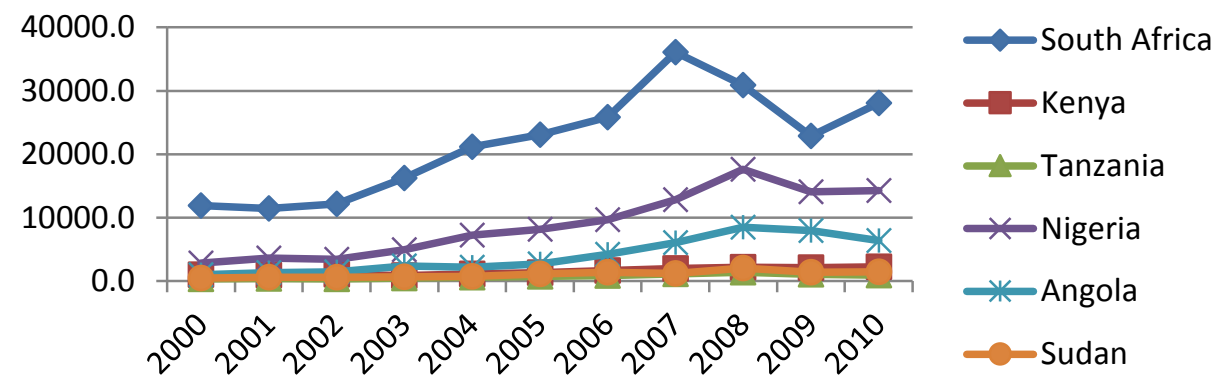

Table 12: European exports to Sub-Saharan Africa 2001-2010 (million USD)

\begin{tabular}{|l|r|r|r|r|r|r|r|r|r|r|}
\hline & $\mathbf{2 0 0 1}$ & $\mathbf{2 0 0 2}$ & $\mathbf{2 0 0 3}$ & $\mathbf{2 0 0 4}$ & $\mathbf{2 0 0 5}$ & $\mathbf{2 0 0 6}$ & $\mathbf{2 0 0 7}$ & $\mathbf{2 0 0 8}$ & $\mathbf{2 0 0 9}$ & $\mathbf{2 0 1 0}$ \\
\hline $\begin{array}{l}\text { South } \\
\text { Africa }\end{array}$ & 11437,2 & 12174,4 & 16252,9 & 21176,5 & 23077,0 & 25850,3 & 36060,6 & 30905,3 & 22897,2 & 28057,1 \\
\hline Kenya & 925,8 & 1064,1 & 911,0 & 1122,1 & 1358,6 & 1679,3 & 2008,2 & 2184,8 & 2112,9 & 2232,9 \\
\hline Tanzania & 389,9 & 372,6 & 505,4 & 612,7 & 739,0 & 867,3 & 1137,5 & 1404,3 & 1099,9 & 958,5 \\
\hline Nigeria & 3615,3 & 3420,1 & 4940,2 & 7221,7 & 8161,7 & 9711,0 & 12822,1 & 17623,3 & 14092,5 & 14310,7 \\
\hline Angola & 1352,0 & 1456,1 & 2369,8 & 2224,2 & 2747,1 & 4207,2 & 6093,7 & 8493,9 & 7948,5 & 6374,2 \\
\hline Sudan & 637,1 & 593,0 & 657,2 & 773,6 & 1155,5 & 1390,1 & 1237,3 & 2051,3 & 1413,1 & 1440,5 \\
\hline
\end{tabular}

Although Europe is one of the largest partners of Africa, if not the largest, for Europe itself African trade is relatively small compared to Europe's other trade partners.

\section{European Foreign Direct Investments in Sub-Saharan Africa}

The European Union is the largest source of FDI in the world economy. Europe is a net investor, its outward investments exceed investments in Europe. The main destinations for the European Union's FDI are other non-EU members and the United States (Eurostat 2010). In 2007, FDI reached its highest level of 530 billion dollar, but after the financial crisis this dropped to 263 billion dollar in 2009. The European Union held 153 billion dollar in FDI stock in Africa by the year 2008, or $4.7 \%$ of its total invested stock. In 2008, the level of FDI flows show that 18.5 billion dollar was directed to Africa. The main investment partner was Egypt, which received about 50\% of total FDI flows (Eurostat 2010). 
Figure 6: Europe's investment position in Africa (millions USD)

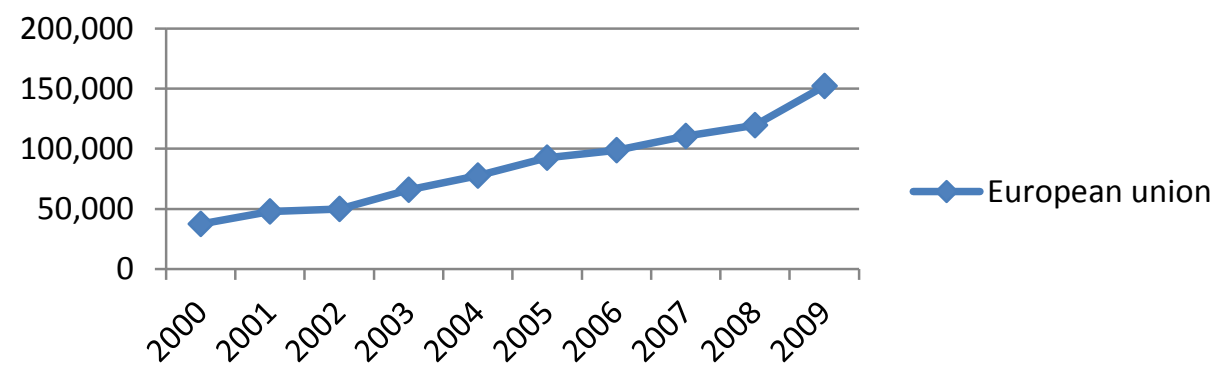

Since 2000, the investment positions of Europe have steadily increased from 40 billion to 153 billion by 2009. This graph shows that even while the total level of FDI positions decreased during the financial crisis, FDI positions in Africa increased. The rate of return of African investment is currently the highest with $17 \%$ and therefore it is an attractive investment destination (Eurostat 2010). The steady economic growth that African countries experience is also reflected in this graph, while FDI normally fluctuate with the state of the economy.

The data on direct foreign investments is monitored by Eurostat in cooperation with the partner countries, however the data of FDI is not complete for the European Union. Eurostat has aggregate data for different regions even the African regions, and while a country by country breakdown is possible, not all of the data is actually available. Consequently, this research can only show the developments for the available countries and within our data set the information is only available for South Africa and Nigeria. These happen to be the largest trade partners of both Europe and India and are both from a different data set (Keers \& Pennink 2010).

\section{European Development Aid in Sub-Saharan Africa}

The third economic component in the economic relation between Europe and Africa is development aid. The OECD also uses the official term "development assistance" and this comprises contributions from donor government agencies at all levels, it also includes debt cancellation. Debt cancellation or debt relief plays an especially large role in aiding developing countries; this was part of the Heavily Indebted Poor Countries (HIPC) initiative launched by the IMF and World Bank (G8 2006). The main recipient countries in Sub-Saharan Africa include the four countries that make up the data set for this study Tanzania, Sudan, South Africa and Kenya in that particular order (EU Donor atlas 2010). In 2008 Germany was the largest donor in the European Union followed by France and the Netherlands. The following graph shows the development assistance of Europe to the selected countries. The level of aid has increased over the years. In 2000 it was around 1,5 billion dollar after which it increased to the level of 2-3 billion annually. There is a large increase in the year 2005-2006. In this year in Europe there was a large write-off of debt, with Nigeria and Sudan as main beneficiaries. Hereafter, the level of development assistance went back to 2-3 billion. "In 2008 president Barrosso of the European Union condemned European countries that allegedly promised to increase aid by 0.56 per cent by 2010 and 0,7 per cent of GDP by 2015, while European countries actually decreased aid over this period" (Kohnert 2008) 
Figure 7: European development aid in Sub-Saharan Africa (millions USD)

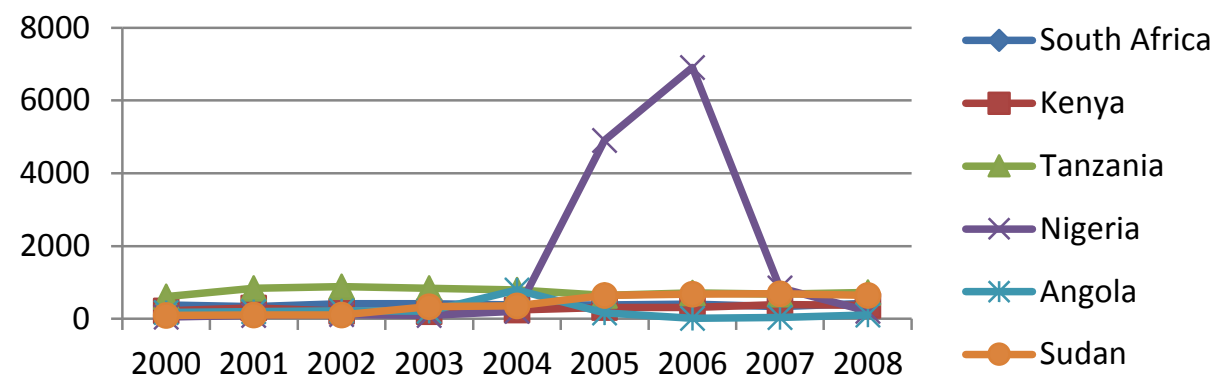

European development assistance in granted to African countries, but they have to adhere to governance reforms. For instance, trade liberalization (see trade agreements), promotion of democracy and human rights.

\section{European Trade Agreements with Sub-Saharan Africa}

The European commission negotiates and coordinates trade agreements with- on behalf of the European member states with counterparties. Thereafter the European Council and parliament need to formally agree the trade agreements. Europe has several trade agreements in place with the African region including the Cotonou Agreement, Economic Partnership Agreement (EPA) and Everything But Arms agreement (EBA) (European Commission 2011).

The Cotonou Agreement was signed in 2000 by the EU and the African, Caribbean and Pacific countries (ACP), and aimed at poverty eradication, sustainable development and a gradual integration of the ACP countries into the world economy (European Commissio 2010). The treaty is designed to continue until 2020, and the treaty grants ACP countries duty-free access to Europe. The EPA negotiations between Africa and the EU are troubling as African nations feel that it is too favorably towards Europe. The main difference between the EPA and the Cotonou Agreement is the reciprocal access, meaning that Europe would also get duty-free access to ACP countries.

These EPA negotiations are held between the EU and various communities within ACP, which enables the trade agreements to focus on the needs of the counterparty. Besides these economic partnership agreements, most countries within Africa fall under the Everything-ButArms category (EBA) (European Commission 2009). This is the most favorable trade regime at this moment, with duty-free-access for all products except arms without quantitative restrictions. The United Nations determines which countries fall under the EBA regime. There are currently 49 least developed countries. The countries Angola, Sudan and Tanzania are on this list.

South Africa is part of the South African Development Community (SADC) region and it is the largest participant in this group. There are thirteen members in SADC of which six members, South Africa, Angola, Botswana, Lesotho, Mozambique, Namibia and Swaziland negotiate via SADC with the EU. The seven other members within SADC negotiate through other region groups with the EU. The economic partnership between SADC and the EU offers no duties/quotas for imports to the EU, it also grants the EU the same right for most of its imports to the participating countries. Moreover, the SADC still has the right to reinstall duties to protect its market. The agreement also includes clauses for Angola and South Africa to join this accord (European Commission 2010). However, South Africa is not likely to join this agreement as it has a separate more comprehensive partnership with the EU, the Trade Development and Cooperation agreement (TDCA). The TDCA in addition covers cooperation 
and development of energy, free flow of capital and social development (European Commission 2009).

Tanzania, Kenya, Uganda, Burundi and Rwanda together form the East African community (EAC). Kenya is the only member of this community that is not part of the Everything-But-Arms agreement. In the agreement with Kenya, there are still some special sectors that need to be protected namely, coffee, tea, spices, meat and dairy.

Nigeria is part of the economic community of West African States (ECOWAS) that is reluctant to agree on terms of an Economic partnership with the EU. Especially Nigeria is opposed to the current negotiations and the terms proposed by the EU.

As mentioned, there is some controversy regarding these trade agreements between Europe and Africa. The leverage of Europe over Africa is large, the pressure for Africa to concede is mounting because with the ending of former agreements, tariffs will be reinstalled, and possibly damage trade flows. Second, Europe is a large donor of African countries and aidnegotiations are simultaneously being discussed, which puts additional pressure on African countries to concede. The phrase "trade for aid", often heard in Europe can be seen here in a different perspective. Third, the countries in the African communities vary in terms of development with other partner countries, some partners are part of the EBA agreement, while others are not. Moreover, when a partner comes to an agreement with Europe, this puts additional pressure on the other members. Although, the agreements leave room for protection of infant industries, it is especially negative for African countries that open their markets for European products (mostly manufactured goods and equipment), while Europe subsidizes its agriculture sector, which happens to be one of Africans export products. Consequently, African producers will still have trouble competing with European producers, while Europe gains free access to Africa facing little competition.

\section{Is the Economic Relationship Beneficial? European perspective}

The relationship with Sub-Saharan Africa is complex, and one should take the colonial history into consideration when analyzing the total relationship. The total level of trade with Africa is for Europe relatively small, in comparison with other regions. As an investment destination it is an attractive destination given the favorable rate of return of $17 \%$. The development assistance to Africa is quite high, but Europe feels morally obliged to support Africa, regarding its colonial role. Europe is giving development aid on the condition that Africa will develop western governance principles and improve human rights and democracy. In the long run it can profit from the improved frameworks, but in the short run it is not very effective. Finally, the new developments in negotiating trade agreements are in favor of Europe, as Europe hopes to gain duty free access to the African countries as well. All in all, Africa is also an important partner for diversifying energy needs, and one could expect that the aforementioned efforts will contribute to having access to oil and other natural resources.

\section{Sub-Saharan Africa perspective}

The economic relationship with Europe is still the largest of Africa, in most African countries Europe is the largest exporter and importer. Furthermore, Europe is the largest source for foreign direct investments and academics regard FDI as a tool to integrate Africa into the world 
economy. Development aid is also important for Africa, however, Europe aims that African countries develop western governance principles while African countries rather develop their infrastructure instead. This infrastructure is important in the short run, and as African governments feel that, certain governing principles Europe tries to enforce should be their own choice to decision to make. Trade agreements are important for Africa, and the current trade agreements make it possible for Africa in most cases to export duty-free, while their own market is still protected. The trade negotiations are still in progress, and would grant Europe duty free access into Africa, this would be unfavorable for African countries as they receive a large part of their income from tariffs.

\section{Balancing the Score for India and Europe}

The previous paragraphs dealt with analyzing the economic relationship between India, Europe and Africa. The four factors analyzed were trade, investments, aid and trade agreements. The previous chapters analyzed trade on an individual basis, but this chapter will jointly present the data to give a more comprehensive perspective on the economic relationship between Africa, India and Europe. The data collection process was rather problematically. Indian data on FDI for individual countries is non-existent in the public domain, while its development data is also not available as development assistance is a joint responsibility of separate ministries. The development aid data used for this study is therefore based on statements by government officials and press releases. Nevertheless, this section will provide a comprehensive comparison between Indian and European engagements with Africa.

\section{Trade Sub-Saharan African Countries}

\section{Trade with Oil Importing Sub-Saharan African Countries}

The main focus of this study is whether Indian engagement is substituting the traditional European-African relation. Furthermore, this study expects that the results might vary for resource rich and labor abundant countries. The intensity of engagement is expected to be higher in the oil exporting countries as oil plays a vital role in the India-African relationship. The oil-importing countries South Africa, Kenya and Tanzania are analyzed first, and in the second section the same analysis will be provided for the oil-exporting countries, Nigeria, Angola and Sudan.

\section{South Africa}

South Africa is the biggest economy of the African continent, and has an abundant supply of natural resources, mainly precious stones and minerals such as gold, diamonds and platinum, but not that much oil. It also has a well-developed industrial and services sector. South Africa is also the African nation that is most integrated into the world economy. The trade statistics show that India and Europe are both increasing their engagements with South Africa. The trend line shows a similar linear curve, however on closer inspection it can be seen that the level of trade between Europe is in absolute terms tenfold the trade between India and Africa.

Figure 8: India South Africa trade (millions USD)

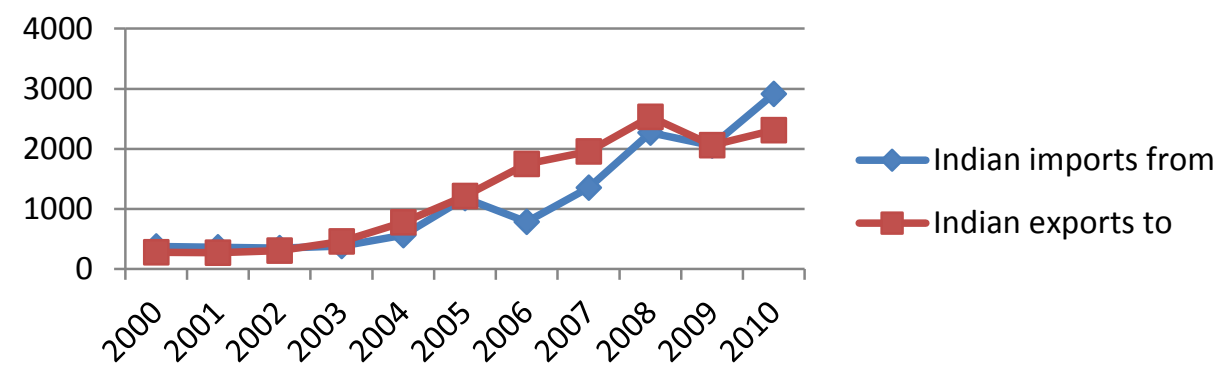


Figure 9: European South Africa trade (millions USD)

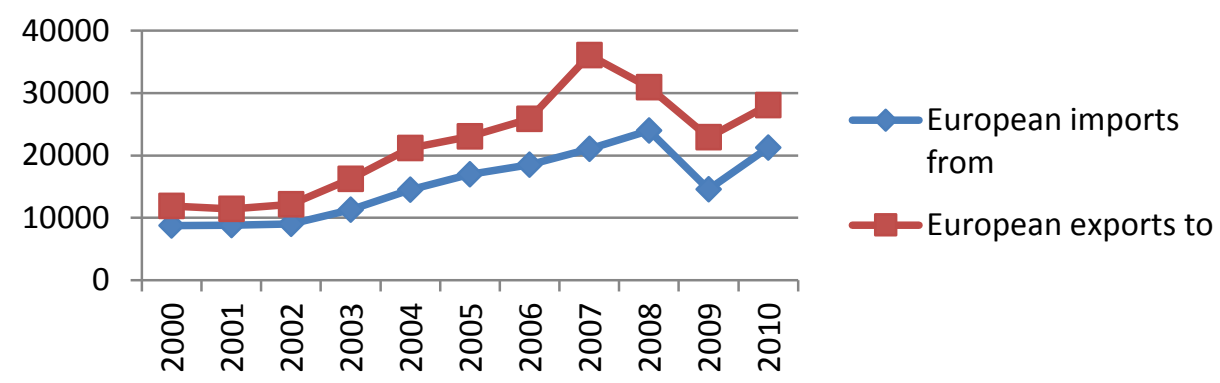

Figure 10: South African trade with India and Europe (millions USD)

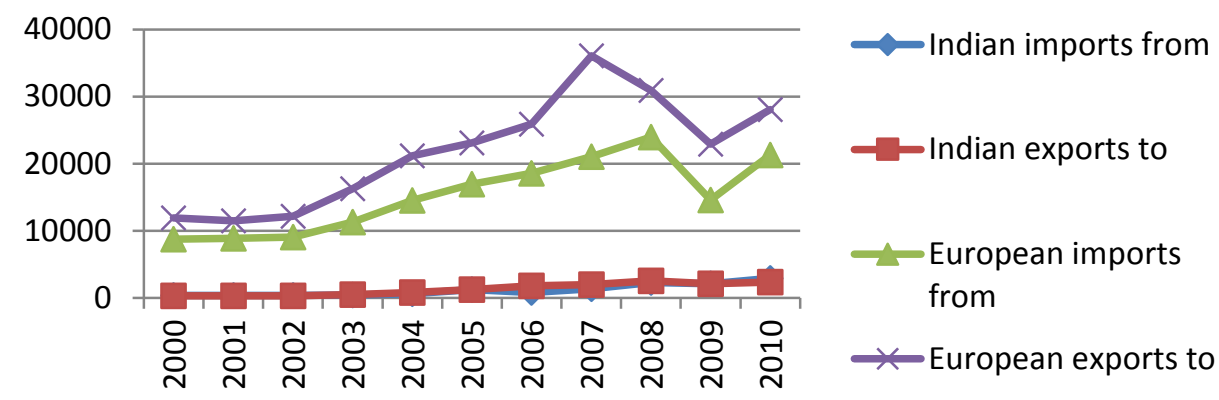

Figure 11: Percentage change trade flows (millions USD)

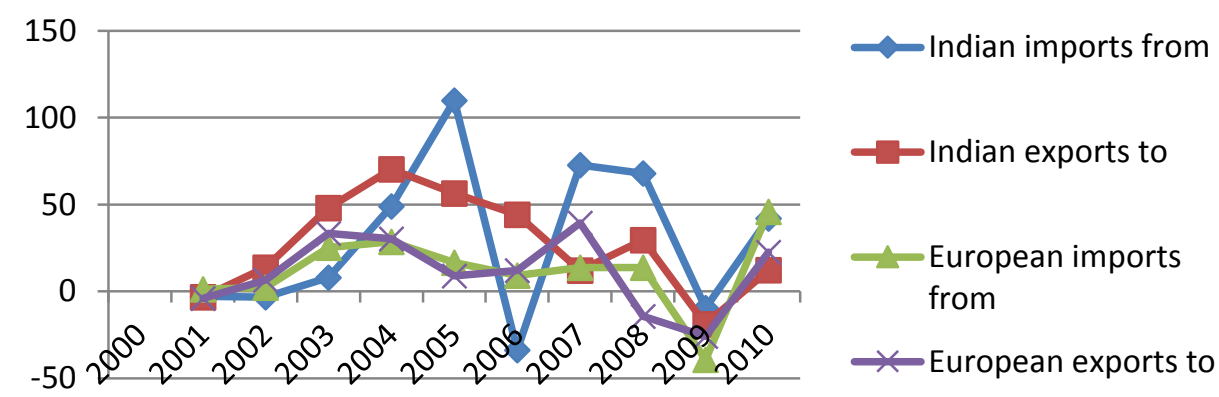

\section{Kenya}

Kenya lies at the Eastern coast of Africa and, although separated by the Indian Ocean, it is geographically Indian's neighbor, (Voll 2010). Kenya is not endowed with many natural resources, and Kenya's most important export products are tea, coffee, horticulture and fish. While the most important import products are industrial supplies, machinery and equipment.

The trade data shows that Kenya's imports from India and Europe are higher than its exports to these countries. Since 2004, Indian exports to Kenya have rapidly increased, and at a higher rate of growth than Europe. However, European exports are still ahead and also increasing. The level of Indian imports from Kenya is quite low, and far below European imports from Kenya. The trade between Kenya and Europe is more balanced with export and imports at a similar level. 
Figure 12: India Kenya trade (millions USD)

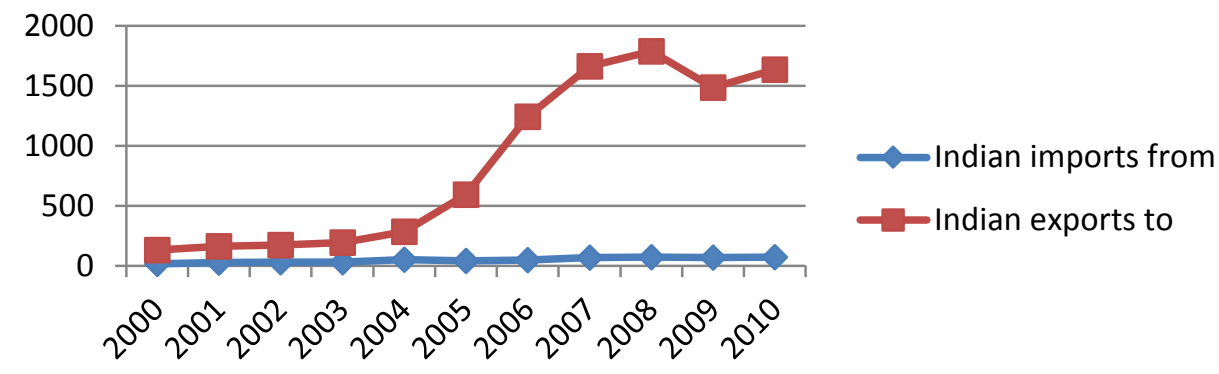

Figure 13: Europe Kenya trade (millions USD)

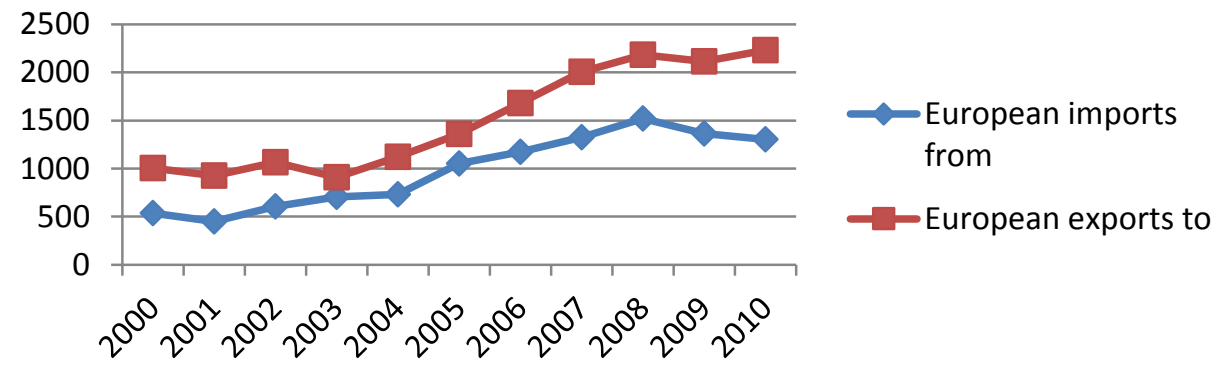

Figure 14: Kenya trade with India and Europe (millions USD)

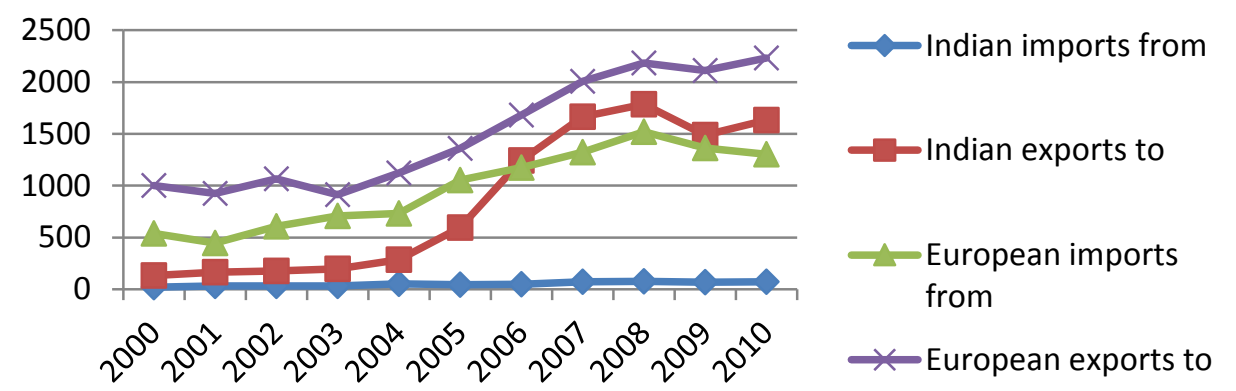

Figure 15: Percentage change trade flows (millions USD)
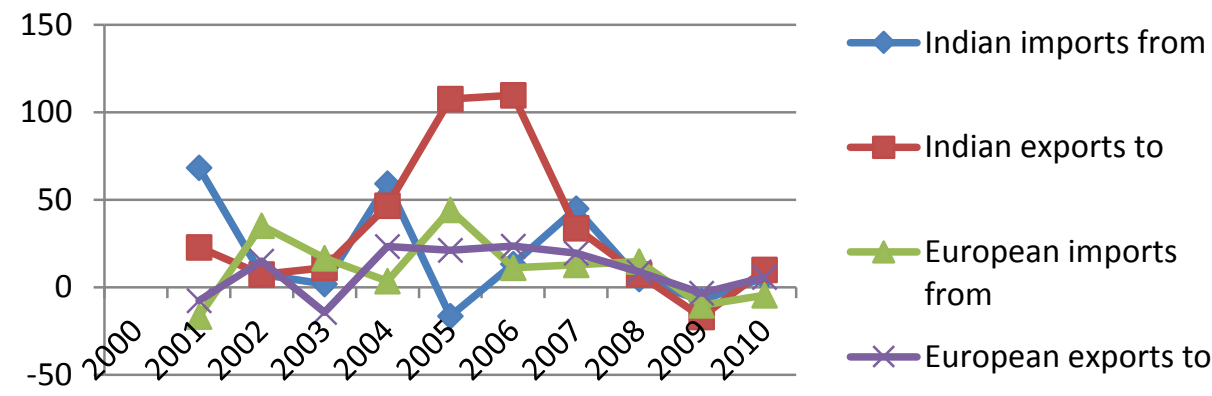

\section{Tanzania}

Tanzania is another Eastern African country, in the backyard of India, and is one of the fastest growing economies of the continent. The backbone of the economy is its agriculture sector that produces tea, coffee, tobacco and a variety of nuts. However, its most valuable exports are capital goods, followed by consumption goods. At the same time, its main imports are capital goods, followed by fuel and transport goods. Tanzania imports from India and Europe are higher than its exports to these countries. The difference in the level of Tanzanian imports from Europe and India is smaller than the difference was for both countries with Kenya, but Europe's imports are still nearly double Indian imports. Indian exports to Tanzania doubled in 
2008, in 2010 it even surpassed European exports, which decreased for the second consecutive year in a row.

Figure 16: India Tanzania trade (millions USD)

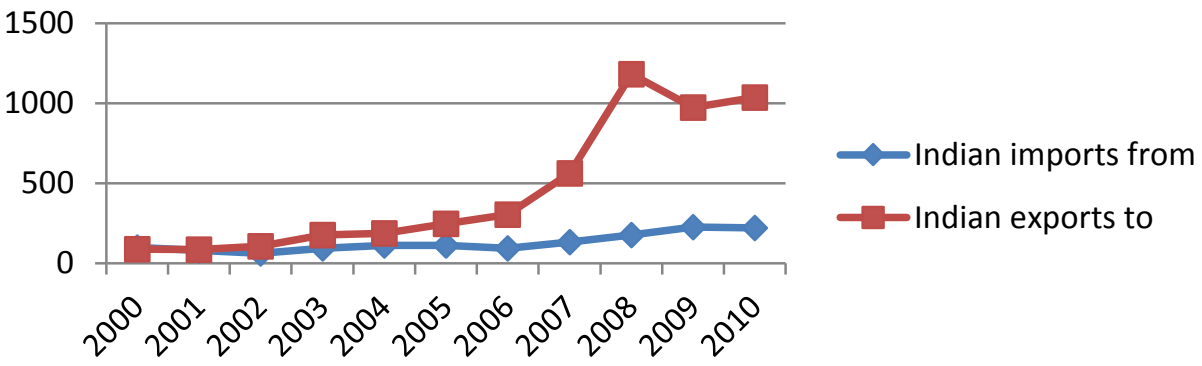

Figure 17: Europe Tanzania trade (millions USD)

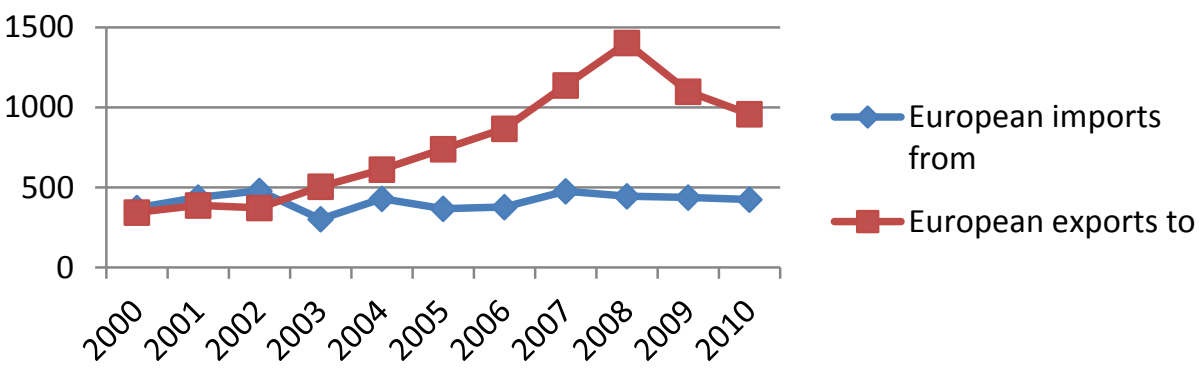

Figure 18: Tanzania trade with India and Europe (millions USD)

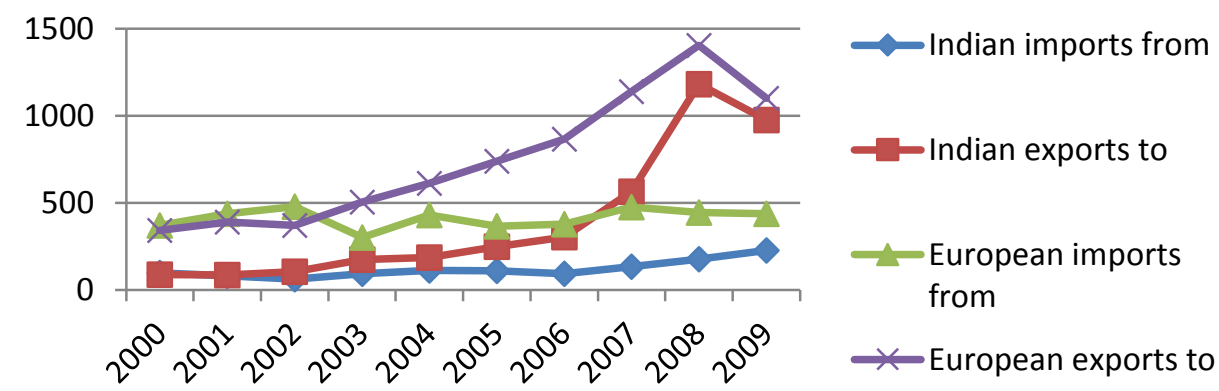

Figure 19: Percentage change trade flows (millions USD)

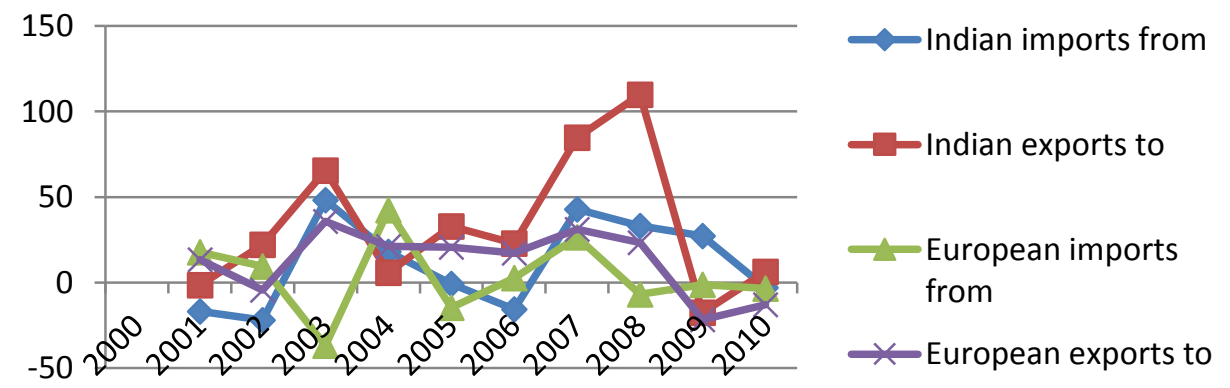

All in all, the trade data between India, Europe and the data set of oil importing countries show that the trade of Europe is still larger than Indian trade. In Tanzania and Kenya the differences 
in the level of exports from India and Europe are getting smaller, but it seems that India mostly exports to these countries, and imports stay behind. Tanzania is the only country of this data set in which India surpasses Europe in exports, but in overall trade Europe is still ahead. The case of South Africa is different than the other countries. India has increased its imports and exports with South Africa, but the European level of trade is almost tenfold that of India's level of trade. The level of Indian imports from South Africa is high compared to the imports from the other countries in the data set, which might by due to its gold imports from South Africa.

\section{Trade with Oil Exporting Sub-Saharan African Countries \\ Nigeria}

Nigeria is the largest oil exporter within Africa and a member of OPEC. Oil is a major feature of the Nigerian economy and together with current oil prices, makes Nigeria one of the world's fastest growing economies. However, the Nigerian economy is not solely dependent on oil, as it is also the third largest manufacturer in Africa, and it has the fifth largest banking sector within Africa (Focus Africa 2011). The main export products of Nigeria are crude petroleum and liquid natural gas, while its main imports are manufactured goods, machinery and transport equipment (CIA World Fact Book).

The trade data for Nigeria illustrates the sudden rise of India's involvement in oil-exporting Africa, but the data also shows European imports rise. In 2005, India was not very active in Nigeria and in 2006 this changed, as imports increased seventyfold. Hereafter, growth rates of Europe and India were comparable, although European imports were already at a much higher level. The export data of India and Europe to Nigeria are different, the Indian exports increase but it is in no comparison to its imports. While, the trade relation of Europe and Nigeria is more extensive, as European exports are almost equal to its imports.

Figure 20: India Nigeria trade (millions USD)

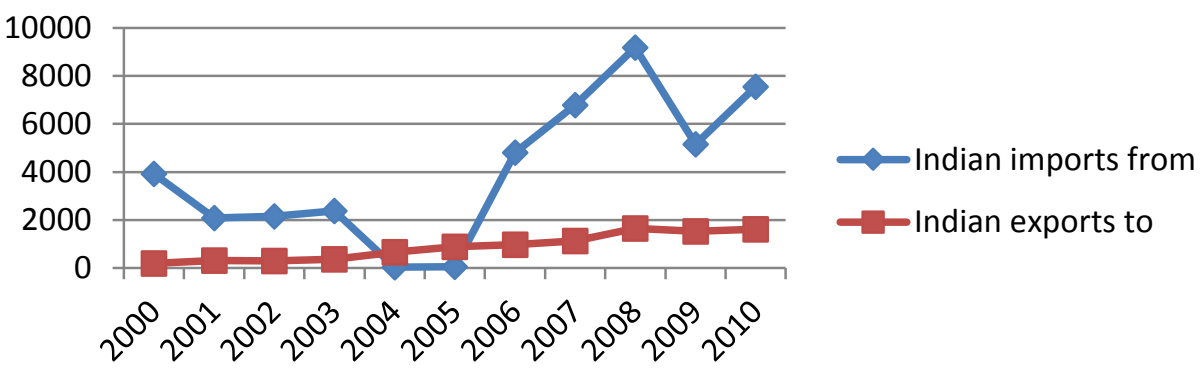

Figure 21: Europe Nigeria trade (millions USD)

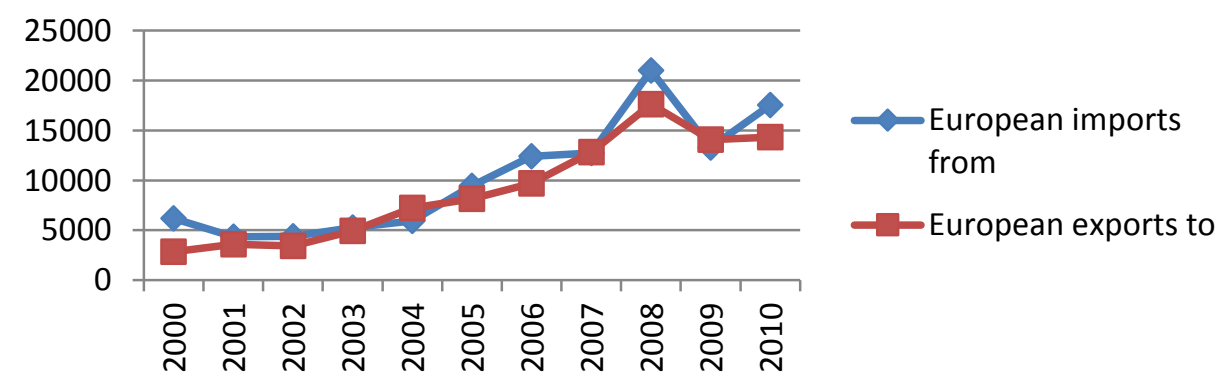


Figure 22: Nigeria trade with India and Europe (millions USD)

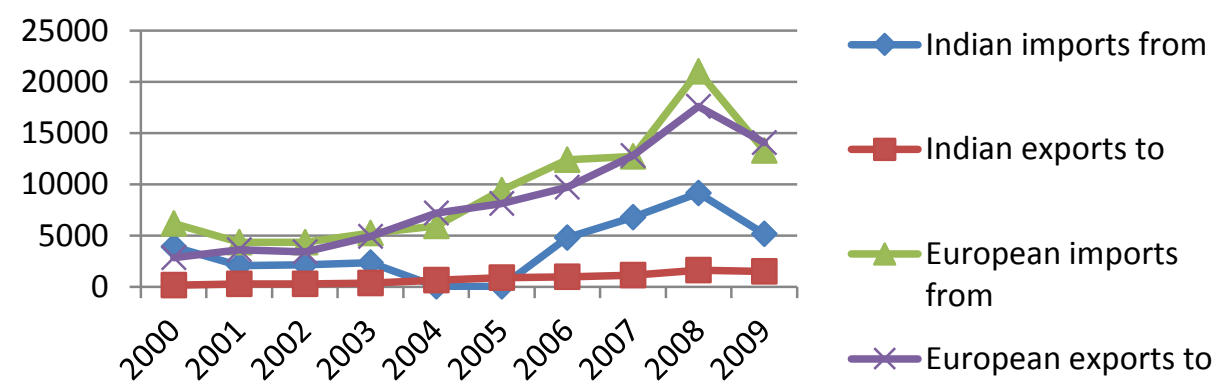

Figure 23: Percentage change trade flows (millions USD)

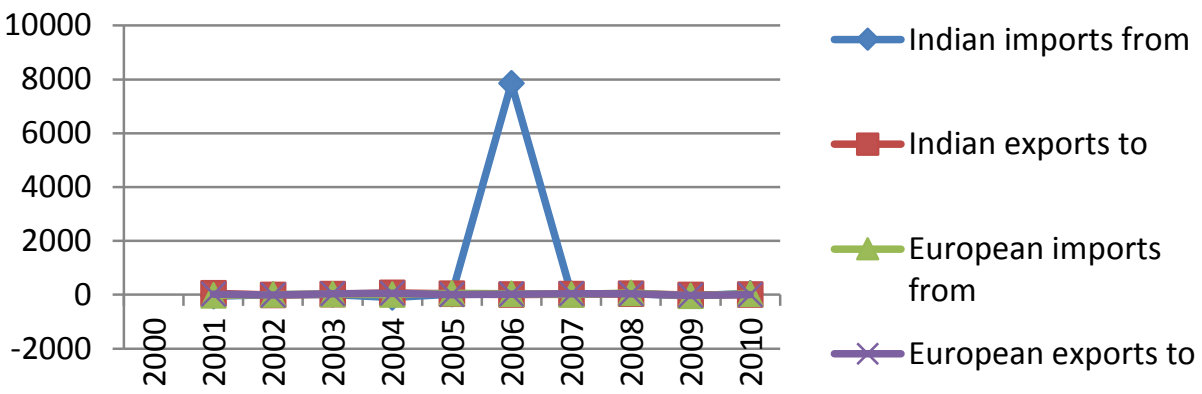

The data shows that Europe is currently a larger trade partner of Nigeria than India. The following quote of the Nigerian minister of commerce and industry captures the foresights for Indian-Nigerian trade: "We want bilateral trade to grow from the present level of 10 billion to 50 billion in 2015" (HinduBusinessline 2010). Furthermore, the minister acknowledges the dominance of oil in the trade relation, but Nigeria is also negotiating for lower tariffs of other products than oil, to increase the level of these goods as well.

\section{Angola}

The Angolan economy is very dependent on oil-exportation, which makes up 94\% of its export, Angola became a member of OPEC in 2006 (Focus Africa 2011). The Angolan economic growth is therefore related to the development of the price of oil. As the oil price skyrocketed in recent years, this resulted in double-digit growth for the Angolan economy. Besides its oil exports it also exports diamonds, while consumer and capital goods are its main imports.

The trade data shows that both India and Europe have intensified the trade relation with Angola. In 2006 India and Europe started increasingly importing from Angola, and Europe even doubled imports from 2007-2008. Hereafter, it started dropping, maybe as a consequence of the financial crisis. On the other hand, India experienced growth from 2006 on, and in 2010, the level of imports came close to the European level. The exports of India and Europe are not the same, Europe exports to Angola are tenfold the level of India. 
Figure 24: India Angola trade (millions USD)

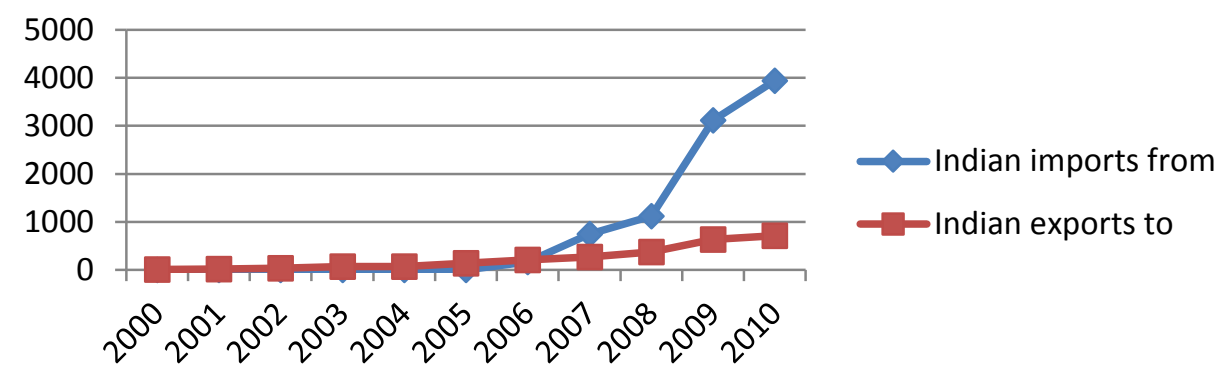

Figure 25: Europe Angola trade (millions USD)

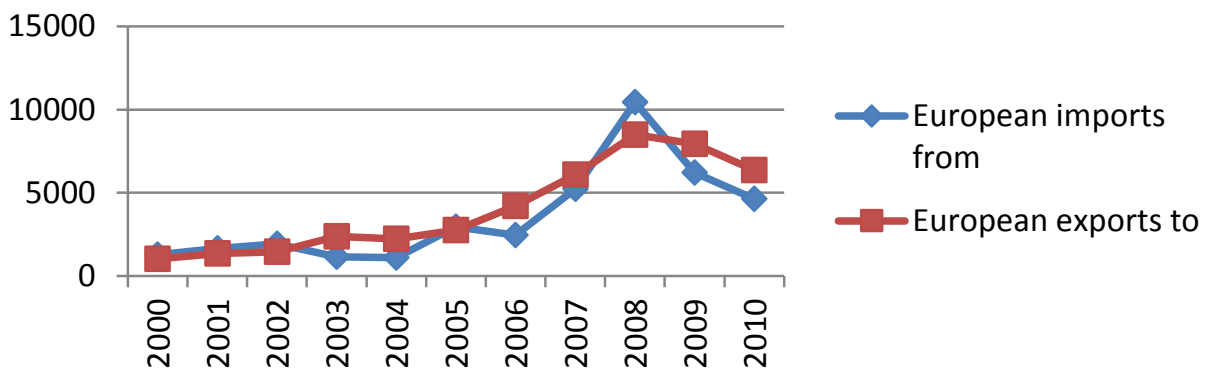

Figure 26: Angola trade with India and Europe (millions USD)

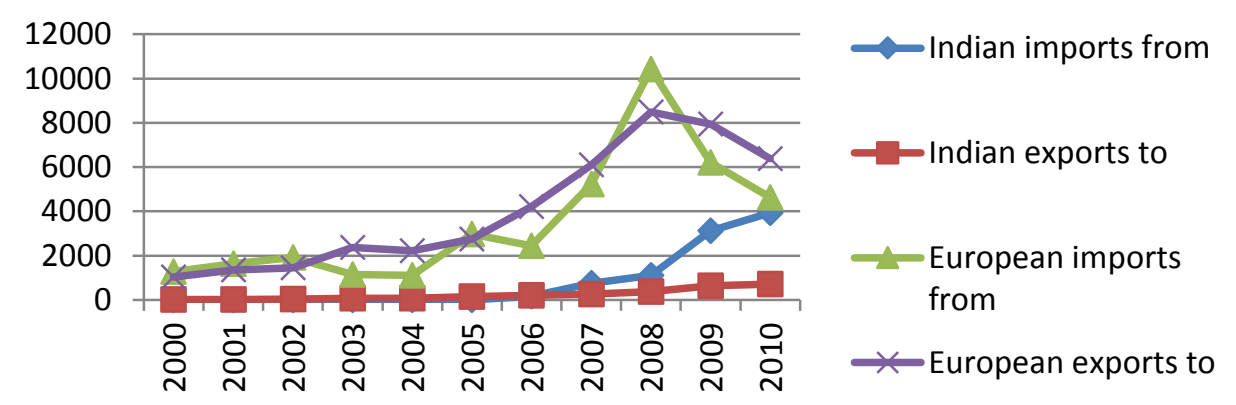

Figure 27: Percentage change trade flows (millions USD)

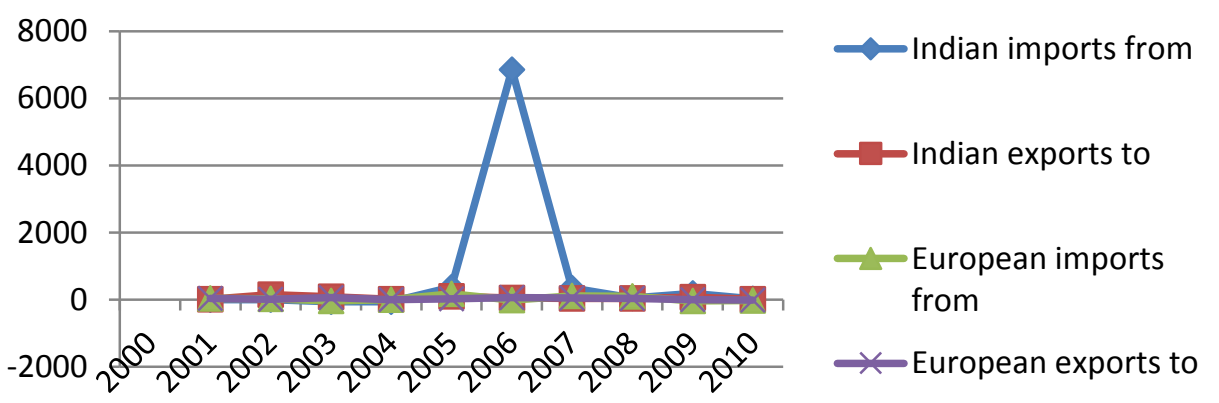

\section{Sudan}

Sudan is the last country within our data set of oil exporting countries. While it now thrives on oil-exports, before it mostly concentrated on the agriculture sector, which is still important for its economy (Focus Africa 2011). The main exports are petroleum and oil, followed by cotton and sesame seed. The main import products are food, manufactured goods and refinery equipment (Website CIA).

Analyzing the trade data it show a different image for India and Europe, while India increased its imports from Sudan, Europe does not import much from Sudan. For both countries the exports to Sudan are higher than the imports, and the European exports are at a much higher 
level than Indian exports. Although the level of Indian imports is lower than in the other oilexporting countries within our data set, it is a large increase from the initial level in 2006. Since 2008, there has been a new up rise of the civil war in Sudan, and it might have significantly affected the level of European imports.

Figure 28: India Sudan trade (millions USD)

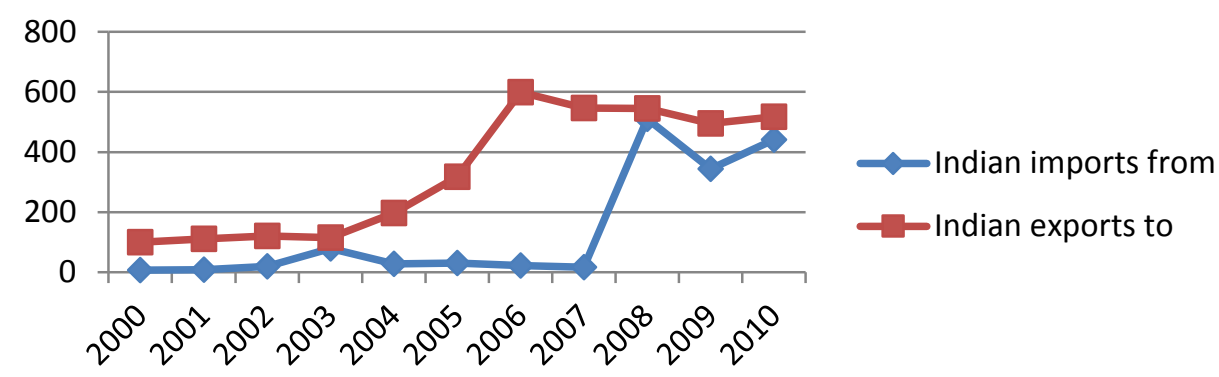

Figure 29: Europe Sudan trade (millions USD)

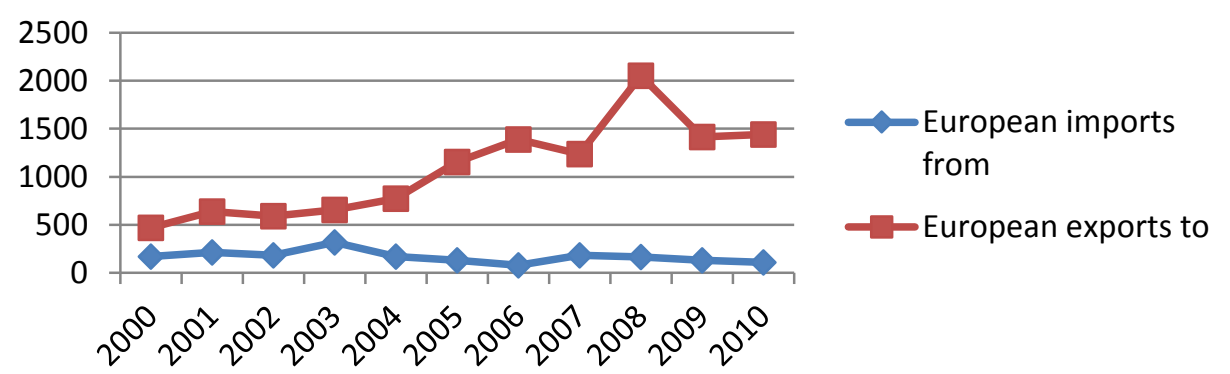

Figure 30: Sudan trade with India and Europe (millions USD)
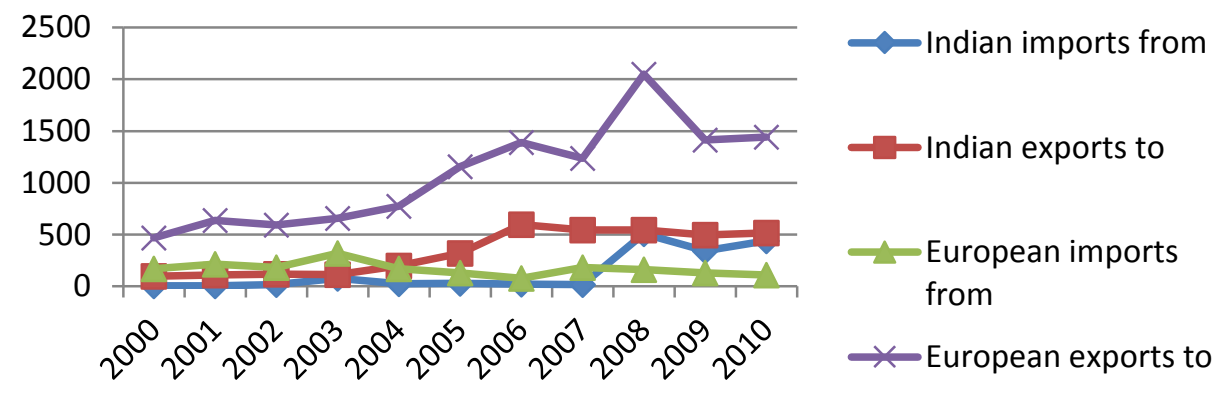

Figure 31: Percentage change trade flows (millions USD)

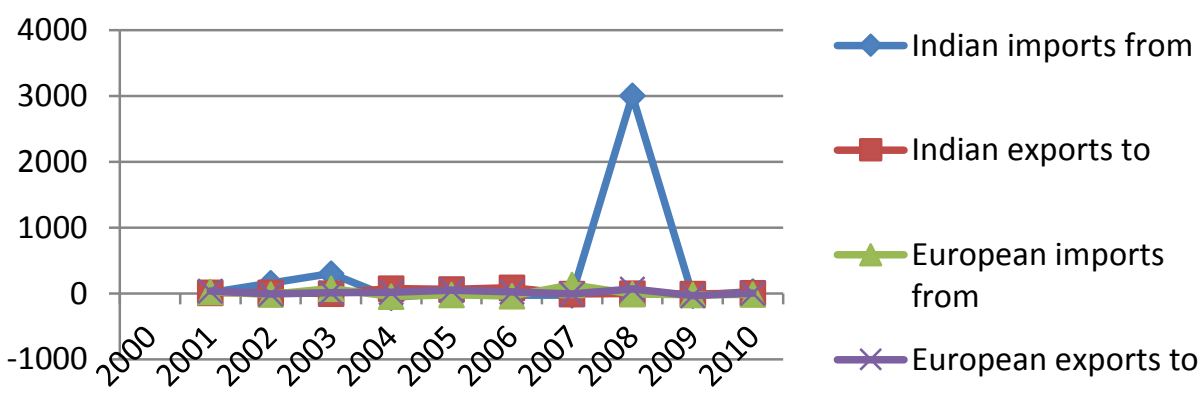

Overall the trade data of the oil exporting countries shows a good picture of the trade relationship of Europe and India. While India's increased level of imports from the oil 
exporting countries is evident, the rise of European imports was also clear. More importantly, India imports mostly from the African countries, but does not reach the European level of export to these countries. This reinforces the image of India acting to secure its energy needs and the resulting resource driven partnership of India and Africa.

In conclusion, the trade relationship of India and Africa is mostly directed to imports from oil exporting countries, but remains lower than European imports. The level of exports of India to Africa is quite low in comparison to the level of exports by Europe. The figures show a definite rising of India in Africa, and as for now, it is mainly imports from Africa, resulting in a net surplus for Africa, which it could possibly reinvest.

\section{Foreign Direct Investment in Sub-Saharan Africa}

The role of FDI in integrating Africa into the global economy is important, and therefore it is unfortunate that not all of the data is available for both India and Europe. While the data for Europe is limited to South Africa and Nigeria, the data for India is non-existent in the public domain. However, there is some literature available on this topic, and major investments are mentioned in press releases. This paragraph will try to combine the available data with an overview of Indian investments. The data will focus on the FDI flows because these are reported annually, and the positions are a consequence of these flows.

Figure 32: European direct investment flows to South Africa (million USD)

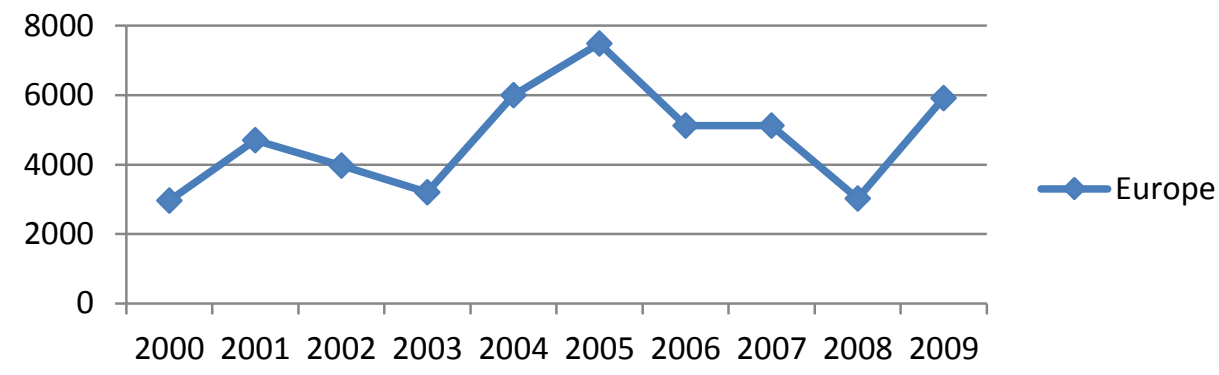

Table 13: European direct investment flows to South Africa and Nigeria

\begin{tabular}{|l|r|r|r|r|r|r|r|r|r|r|}
\hline & $\mathbf{2 0 0 0}$ & $\mathbf{2 0 0 1}$ & $\mathbf{2 0 0 2}$ & $\mathbf{2 0 0 3}$ & $\mathbf{2 0 0 4}$ & $\mathbf{2 0 0 5}$ & $\mathbf{2 0 0 6}$ & $\mathbf{2 0 0 7}$ & $\mathbf{2 0 0 8}$ & $\mathbf{2 0 0 9}$ \\
\hline $\begin{array}{l}\text { South } \\
\text { Africa }\end{array}$ & 2958 & 4700 & 3971 & 3197 & 6005 & 7487 & 5124 & 5118 & 3018 & 5918 \\
\hline Nigeria & & & & 260 & 423 & 3143 & 1802 & 1917 & 1877 & 771 \\
\hline
\end{tabular}

Source: Eurostat

As mentioned, Europe is the largest source of FDI worldwide, and EU companies are a key source for investments in South Africa. This surge in investments comes mainly from new investments by formerly South African multinationals now headquartered in the United Kingdom (Thomas \& Leape 2005). India invests mainly through private companies, and currently 96 companies are active in South Africa. Among these are Tata Mahindra \& Mahindra most know and the largest (Cheru \& Obi 2011; Singh 2007). The investment flows of Europe are relatively constant around 5-6 billion. 


\section{Figure 33: European direct investment flows to Nigeria (million USD)}

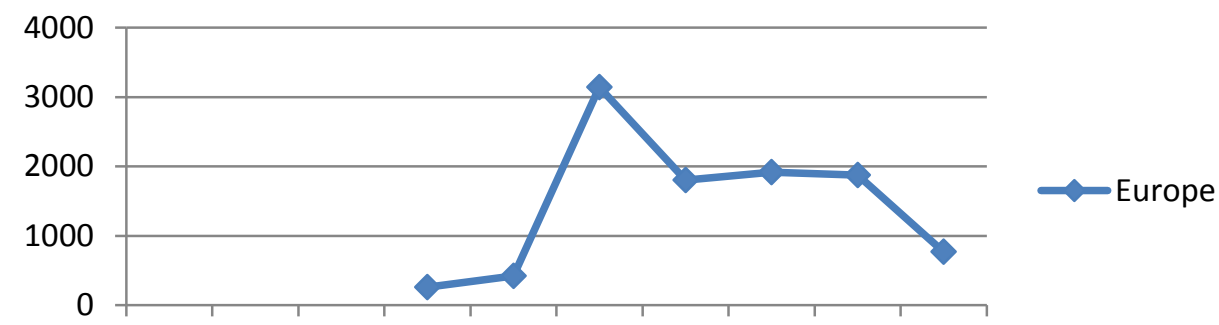

2000200120022003200420052006200720082009

European investments in Nigeria are smaller than the investments in South Africa. The level of investment is around 2 billion dollar, with the Netherlands as an important investor. It might seem strange that the level of investments are smaller in a resource rich country, but then again, the investment climate of South Africa is more favorable because as it is more stable. In contrast there is a lot of turmoil in Nigeria with terrorist attacks on oil stations. The level of European investments in Nigeria even decreased to less than one billion dollar in 2009. It was estimated that India is increasing its engagements with Africa in order to secure its energy needs, and the following statement certainly supports this claim:

"India has agreed to invest six billion U.S. dollars in power plants and other projects in Nigeria, Indian Deputy High Commissioner to Nigeria Anil Trigunayat said at the weekend"(People's Daily 2006). The six billion is also mentioned in the article of Singh (2007) and labeled an oil infrastructure deal.

"Trigunayat expressed India's desire to collaborate with Nigeria for the benefit of both countries, saying that India was also interested in engaging in joint venture projects with Nigeria in the oil and gas sector" (People's Daily 2006).

The level and presence of India as an investor in Africa is increasing, while the level of investments from Europe is fluctuating. The investments in South Africa by Europe are increasing again after a fall, so it's hard to speak of a substitution effect, the fall of investments could also be a consequence of the economic climate. The rise of India's engagement in Nigeria is without questions, and we also see a drop in European investments from 2005. It could be that India is partially the reason for this drop, but it is also known that Europe is reluctant to invest in Nigeria as it's unstable and there are attacks on oil refineries.

\section{Foreign Development Aid in Sub-Saharan Africa}

The data on Indian development aid is relatively scarce, but the rise of India as an emerging donor is a fact. India has been a large recipient of development assistance itself but has limited the number of countries from which it is willing to accept development aid. Simultaneously, it has increased its efforts in development assistance. While India is known for its capacity building and small scale projects, it recently has initialized a large scale pan-African E-network. It also extended large volumes of credit lines, and took part in debt-relief programs. The extension of credit lines of around 5 billion dollar, 700 million dollar for training, and the total costs of the pan-African e-network of 1 billion dollar amount to 6.7 billion dollar over a three year period. 
The development assistance of the European Union to Africa seems unaffected by the development aid of India. In 2000, the total amount of development assistance by the EU to the six countries in the data set was 1,5 billion dollar, and over the years has increased to the level of 2-3 billion dollar annually. However, in the years 2005-2006 it even reach levels of 7 and 9 billion dollar respectively. Over the entire period it was Tanzania that annually received just less than 1 billion dollar, but Nigeria received the most in the form of debt relief.

All in all, it is a good development for Africa that multiple partners are willing to contribute to the development of the African region. Since the data of India had to be gathered from statements by government officials and estimates in literature, it is not clear whether the suggested figures are in fact the actual contributions. The European data is official and has been steady over the years. The aid figures from India would amount to 2,2 billion dollar annually, while Europe contributes 2-3 billion dollar annually, not taking into consideration the large debt relief program, that by itself exceeds all Indian donations. Therefore, it is clear that although India is rising as a potential donor, but it is not a substitute for European development assistance, which is not affected and remains stable development partner.

\section{Trade Agreements with Sub-Saharan Africa}

The developments in trade agreements nicely illustrate a side effect of the increased engagements of other partners than Europe. As the data has showed, Europe is still the most important import and export partner of most African countries, but with India and other emerging countries increasing their engagement substantially, the African countries have improved their bargaining position with Europe as they are less dependent than before.

India is in negotiation with different African partners to set up preferential and free trade agreements, as these have not been installed yet. India does support the least developed countries, by following the United Nations agreement of giving these countries duty free access to its markets. Within our data set Angola, Sudan and Tanzania fall under this regime. As mentioned, negotiations are in progress, and this is a time consuming process as African countries fall under different Economic communities, which stalls the process. Europe has various trade agreements with African countries the EBA, Cotonou and new Economic Partnership Agreements. Again, Angola, Sudan and Tanzania have duty-free access via TheEverything-But-Arms agreement. Then there is the Cotonou agreement for the African, Caribbean and Pacific region, and this gives these countries also duty- free access, and in addition has agreements covering a range of topics as development, and reforms. Finally, Europe wants to sign a new agreement, the Economic Partnership Agreement, and is in negotiation with African countries. However, these negotiations for the EPA are in an impasse, as the deadline has been postponed due to troubling negotiations. African countries feel they are being pressured, and that these agreements are too much favoring Europe.

In conclusion, the trade agreements between India, Europe and Africa are a necessity for trade and therefore it was not expected to detect a substitution effect. However, the increasing trade with other partners than Europe and the negotiations with India might affect the negotiations between Europe and the African countries. The position of Africa in these negotiations is stronger as it becomes less dependent on Europe, the reluctance of African countries to renew the partnership agreements on Europe's terms indicate that Europe will have to compromise.

\section{COMPARING INDIA AND CHINA}

In many of the available research on Asia's rise in the global economy, and their engagements with Sub-Saharan Africa, China and India are often treated as if they are equal. When analyzing the data and comparing these with the previous research of Keers and Pennink (2010) it seems 
that India operates at a different level than China. India hosted its first India Africa Summit in 2008, while China already started actively engaging Africa in 2000 with its first conference on China Africa cooperation (FOCA 2004). Moreover, Pigato (2009) states that Chinese exports to Sub-Saharan Africa might pose a treat for producers in this region, and simultaneously compete with these producers with their exports to other regions, while India does not pose a similar threat as it focuses more on services that are not yet developed in Sub-Saharan Africa. This claim is supported by this research on the trade between India and Africa and was most present in the exports by oil exporting countries to India, while exports to Sub-Saharan Africa were still little. The research by Keers and Pennink (2010) showed that the trade between China and Africa is more comprehensive and that both imports and exports surged.

Figure 344: China and India import from Sub-Saharan Africa (millions USD)

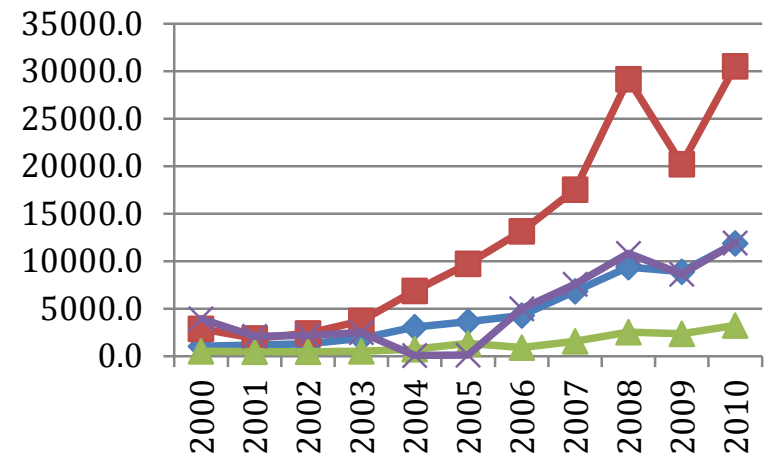

China imports from oil importing countries

- China imports from oil exporting countries

- India imports from oil importing countries 
Table 14: China imports from Sub-Saharan Africa (millions USD)

\begin{tabular}{|l|r|r|r|r|r|r|r|r|r|r|r|}
\hline & $\mathbf{2 0 0 0}$ & $\mathbf{2 0 0 1}$ & $\mathbf{2 0 0 2}$ & $\mathbf{2 0 0 3}$ & $\mathbf{2 0 0 4}$ & $\mathbf{2 0 0 5}$ & $\mathbf{2 0 0 6}$ & $\mathbf{2 0 0 7}$ & $\mathbf{2 0 0 8}$ & $\mathbf{2 0 0 9}$ & $\mathbf{2 0 1 0}$ \\
\hline $\begin{array}{l}\text { South } \\
\text { Africa }\end{array}$ & 1037 & 1173 & 1269 & 1841 & 2955 & 3444 & 4095 & 6608 & 9206 & 8676 & 11424 \\
\hline Kenya & 4 & 6 & 6 & 9 & 17 & 18 & 24 & 28 & 35 & 30 & 39 \\
\hline Tanzania & 5 & 3 & 7 & 28 & 70 & 171 & 152 & 199 & 132 & 194 & 402 \\
\hline Nigeria & 293 & 227 & 134 & 72 & 463 & 527 & 278 & 537 & 510 & 898 & 1068 \\
\hline Angola & 1843 & 722 & 1087 & 2206 & 4718 & 6581 & 10931 & 12885 & 22370 & 14661 & 22810 \\
\hline Sudan & 732 & 938 & 1157 & 1442 & 1705 & 2615 & 1941 & 4114 & 6302 & 4659 & 6654 \\
\hline
\end{tabular}

\section{Source: IMF direction of trade statistics}

Table 15: India imports from Sub-Saharan Africa (millions USD)

\begin{tabular}{|l|r|r|r|r|r|r|r|r|r|r|r|}
\hline & $\mathbf{2 0 0 0}$ & $\mathbf{2 0 0 1}$ & $\mathbf{2 0 0 2}$ & $\mathbf{2 0 0 3}$ & $\mathbf{2 0 0 4}$ & $\mathbf{2 0 0 5}$ & $\mathbf{2 0 0 6}$ & $\mathbf{2 0 0 7}$ & $\mathbf{2 0 0 8}$ & $\mathbf{2 0 0 9}$ & $\mathbf{2 0 1 0}$ \\
\hline $\begin{array}{l}\text { South } \\
\text { Africa }\end{array}$ & 372 & 362 & 350 & 378 & 563 & 1182 & 782 & 1351 & 2269 & 2052 & 2916 \\
\hline Kenya & 18 & 30 & 32 & 33 & 52 & 44 & 50 & 72 & 75 & 69 & 73 \\
\hline Tanzania & 99 & 82 & 64 & 95 & 112 & 112 & 94 & 134 & 179 & 227 & 221 \\
\hline Nigeria & 3919 & 2083 & 2157 & 2392 & 50 & 60 & 4808 & 6790 & 9175 & 5159 & 7553 \\
\hline Angola & 0 & 0 & 5 & 2 & 1 & 2 & 168 & 749 & 1118 & 3117 & 3942 \\
\hline Sudan & 7 & 8 & 20 & 79 & 28 & 31 & 22 & 16 & 510 & 344 & 441 \\
\hline
\end{tabular}

Source: IMF direction of trade statistics

Figure 35: China and India export to Sub-Saharan Africa (millions USD)
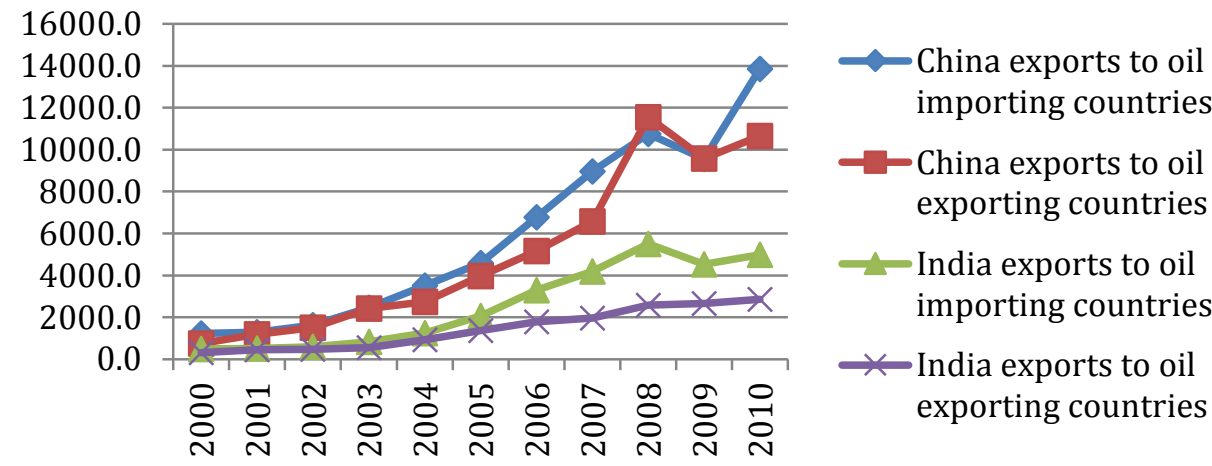

Table 16: China exports to Sub-Saharan Africa (millions USD)

\begin{tabular}{|l|r|r|r|r|r|r|r|r|r|r|r|}
\hline & $\mathbf{2 0 0 0}$ & $\mathbf{2 0 0 1}$ & $\mathbf{2 0 0 2}$ & $\mathbf{2 0 0 3}$ & $\mathbf{2 0 0 4}$ & $\mathbf{2 0 0 5}$ & $\mathbf{2 0 0 6}$ & $\mathbf{2 0 0 7}$ & $\mathbf{2 0 0 8}$ & $\mathbf{2 0 0 9}$ & $\mathbf{2 0 1 0}$ \\
\hline $\begin{array}{l}\text { South } \\
\text { Africa }\end{array}$ & 1014 & 1051 & 1312 & 2030 & 2952 & 3826 & 5769 & 7429 & 8596 & 7366 & 10807 \\
\hline Kenya & 133 & 139 & 183 & 242 & 349 & 457 & 622 & 932 & 1217 & 1278 & 1786 \\
\hline Tanzania & 86 & 90 & 121 & 191 & 216 & 304 & 383 & 596 & 940 & 915 & 1251 \\
\hline Nigeria & 549 & 919 & 1047 & 1787 & 1719 & 2305 & 2856 & 3800 & 6758 & 5478 & 6695 \\
\hline Angola & 34 & 46 & 61 & 146 & 193 & 373 & 894 & 1241 & 2931 & 2385 & 2004 \\
\hline Sudan & 158 & 227 & 392 & 478 & 816 & 1294 & 1417 & 1536 & 1851 & 1705 & 1955 \\
\hline
\end{tabular}

Source: IMF direction of trade statistics 
Table 17: India exports to Sub-Saharan Africa (millions USD)

\begin{tabular}{|l|r|r|r|r|r|r|r|r|r|r|r|}
\hline & $\mathbf{2 0 0 0}$ & $\mathbf{2 0 0 1}$ & $\mathbf{2 0 0 2}$ & $\mathbf{2 0 0 3}$ & $\mathbf{2 0 0 4}$ & $\mathbf{2 0 0 5}$ & $\mathbf{2 0 0 6}$ & $\mathbf{2 0 0 7}$ & $\mathbf{2 0 0 8}$ & $\mathbf{2 0 0 9}$ & $\mathbf{2 0 1 0}$ \\
\hline $\begin{array}{l}\text { South } \\
\text { Africa }\end{array}$ & 279 & 270 & 307 & 454 & 773 & 1210 & 1745 & 1954 & 2533 & 2057 & 2312 \\
\hline Kenya & 133 & 163 & 175 & 195 & 286 & 593 & 1244 & 1664 & 1787 & 1486 & 1634 \\
\hline Tanzania & 89 & 87 & 107 & 177 & 187 & 249 & 305 & 564 & 1183 & 975 & 1036 \\
\hline Nigeria & 199 & 316 & 310 & 377 & 661 & 898 & 986 & 1142 & 1656 & 1536 & 1626 \\
\hline Angola & 14 & 16 & 38 & 68 & 75 & 145 & 207 & 272 & 377 & 633 & 714 \\
\hline Sudan & 100 & 111 & 120 & 115 & 197 & 318 & 599 & 547 & 544 & 495 & 518 \\
\hline
\end{tabular}

Source: IMF direction of trade statistics

The difference in magnitude is clearly represented in the figures. China's exports and imports are higher than those of India in both oil importing and oil exporting countries. The trade relationship of India and China is stronger in oil exporting countries, but India and China export more to oil importing countries.

The comparison of outward foreign direct investments is based on estimates from Keers and Pennink's (2010) research, and on the research of Cheung, de Haan and Qian (2010). The outward direct investments of China show a substantial increase, from 0.5 billion in 2000, 2.5 billion in 2006 and the latest estimate is 6 billion dollar in 2010 towards Africa. The level of Indian outward foreign investments is presumably lower than China (Pradhan 2011), but the proposed investment of India, 6 billion dollar in Nigeria indicates that India is present as an investor. The outward investments of China are presumably higher than India's investments, given the difference in total budget, China's and India's budgets in 2008 were 53.8 and 18.8 billion dollar (Hong 2011).

The level of development assistance has increased substantially for India and China, both countries have a non-interference policy and their contributions to Africa are both aimed at developing infrastructure. However, India also focuses on the development a pan-Africa ENetwork. In literature, India is praised for its small scale and focus on capacity building, moreover this sets India apart from China, which is criticized. Based on the research of Keers and Pennink (2010), and the analysis on Indian development assistance, the numbers are comparable, both countries reaching around 2 billion dollar annually.

In conclusion, this section illustrates the difference in magnitude in the trade relationship of India and China with Africa. The trade relationship of China is stronger and more comprehensive than India's trade relationship with Africa. India mostly imports from Africa, and then mostly from oil exporting countries, China also exports a lot to African oil exporters. Another difference is the focus of India on Nigeria, while China imports more from Angola and Sudan than Nigeria. The level of investments is expected to be higher for China, while development assistance is comparable

\section{CONCLUSIONS}

The aim of this study was to analyze whether the growing economic relationship between India and Africa was a substitute for the traditional relationship between Europe and Africa. The addition of trade agreements to the model captures the developments in other factors, as turmoil in European negations go hand in hand with stronger ties between India and Africa. However, trade agreements themselves have not provided us with additional information on 
the economic relation. Based on the developments in these subjects this study will conclude whether a substitution effect is indeed present. Furthermore, the engagements of India will be placed in perspective by comparing it with China.

The first component of the economic relationship under investigation was trade, although it is evident that the Indian African trade relationship is rising at an impressive pace this provides no substitution effect as the trade between Europe and the African countries simultaneously showed increasing growth. Moreover, the trade relationship between Africa and Europe is more extensive than the trade relationship between India and Africa. The trade between India and Africa is one sided, India's imports have grown, and mostly from resource rich countries, while Europe also imports a lot, but its exports are also at a high level. In terms of trade there is no substitution effect, however the expectation that India's presence in Africa is mostly resource driven is apparent.

The second factor in the economic relationship is foreign direct investment, and the level of outward foreign direct investment of India is increasing. Statements by Indian officials of 6 billion dollar of investments in Nigeria reflect this. Moreover, in South Africa many Indian companies are active, Tata and Mahindra \& Mahindra are well known and have made large investments in South Africa. Europe is world's largest investor, and the FDI flows to South Africa fluctuate around 5-6 billion dollar with the exception of the year 2008. The investments in Nigeria have risen progressively to 3.5 billion dollar in 2006, after which it fell to around 2 billion dollar annually, and in 2009 even to a low of 700 million dollar. The precarious situation in the Niger delta, with attacks on oil refineries might pose a reason for the decrease of European investments. Overall, Africa is an attractive region for investments, with a rate of return of $17 \%$. Europe and India are both active investors, but Europe investments are higher. Thus, this study cannot prove a substitute effect; both parties increasingly invest in Africa, which has a positive effect on Africa as it integrates the continent more and more with the world economy.

The third factor in the economic relation is development aid. Even though data on Indian development aid is scarce, it seems that India is increasingly contributing to the development of Africa. India always had a development aid program, which was relatively small and focused on capacity building, but its development assistance is growing. India uses aid as a channel to promote its importance of a global economy, and it has restricted its own dependence on aid, while at the same time raising its pledges of assisting other countries. Although, promised development aid is not the same as actual development aid, it is noteworthy that India pledged approximately 6.7 billion dollar in development aid over a period of 3 years, and remains the focuses on capacity building. The level of European aid is stable and Europe contributes 2-3 billion dollar annually, so the increased development assistance has not substituted for European aid. This is a good development for Africa, India and Europe have a different approach on development aid and Africa can benefit from multiple donors. India focuses more on infrastructure and E-networks, while Europe addresses governance reforms and improvement of human rights.

Finally, the rise of India in Africa is undeniable and profound in all aspects, but compared to the engagements of China, India still has a lot of ground to cover. China's relationship with Africa consists both high levels of imports and exports. The total outward investments of China are almost double that of India, but in aid assistance India operates at a similar level. The difference can be explained by the longer and more active role China has taken in its engagements towards the African region. 
All in all, this research has found no substitution affect, as both Europe and India are intensifying their economic relationship with Africa. The economic relationship of India does not yet come at a cost for Europe's relationship with Africa. India's economic relationship seems to be stronger in resource rich countries, and points in the direction of India's engagements being mostly resource driven. The relationship of Europe with Africa is still larger than India and China. However, India's relationship might be more beneficial for Africa as it provides Africa with a trade surplus that enables Africa to reinvest this capital into their own economy.

Future research could investigate if South-South trade is becoming more important than North-South trade. Another interesting research gap would be to analyze the diplomatic ties between the BRIC members and Africa, against the diplomatic relationships between Africa and Europe, for instance by looking at which international organizations they share, the number of visits by diplomats, and their importance. Within Europe, there is a large ongoing debate on the effectiveness of development aid, and research into the different approach of developing countries. It would be interesting to investigate this from an African point of view, and analyze their opinion on the different approaches of Europe versus countries as China and India. Concluding, Trade agreements can be removed in follow up studies as it has not proved to add additional value to this research.

\section{References}

Journals

Agrawal, S. (2007), Emerging donors in international development assistance, partnership and business development division, December,

Asiedu, E. (2006), Foreign direct investment in Africa: the role of natural resources, market size, government policy, institutions and political instability, world economy, vol. 29,

Beri, R. (2005) A, Africa's energy potential: Prospects for India, IDSA Strategic analysis, July-Sept

Beri, R. (2008) B, India woos Africa, Institute for defense studies \& analyses, March

Beri, R. (2010) C, Prospects of India's energy quest in Africa: insights from Sudan and Nigeria, strategic analysis, $34: 6, \mathrm{p}$ 897-911

Chanana, D. (2009) A, India as an emerging donor, Economic and political weekly, vol. XLIV, 12

Chanana, D. (2010) B, India's transition to global donor: limitations and prospects, international cooperation and development, $\mathrm{p}$ 1-7

Cheru, F. Obi, C. (2011) $A$, Chinese and Indian engagement in Africa: competitive or mutually reinforcing strategies? Journal of international affairs, vol. 64, no. 2

Cheru, F. Obi, C. (2011) B, Genuine partnership or a marriage of convenience, foreign policy in focus, June

Cheung, Y, W., de Haan, J., Qian, X,W., Yu, S. (2010), China's outward direct investments in Africa, Working paper, SUNY Buffalo state.

Hattari, R., Rajan, R. (2010), India as a source of outward foreign direct investment, Oxford development studies, vol. 38:4, 497-518

Hong, Z. (2011), The expansion of outward FDI: a comparative study of China and India, China: an international journal, March

Goodison, P. (2007), The future of Africa's trade with Europe: "New" EU trade policy, review of African political economy, vol. 34, p 139-151 
Grimm, S., Humphrey, J., Lundsgaard, E., de Souza, L. (2009), European development cooperation to 2020: Challenges by new actors in international development, EDC working paper, no 4

Pal, P. (2008), "Surge in Indian Outbound FDI to Africa: An Emerging Pattern in Globalization?" paper presented at the global studies conference may 16-18, University of Illinois, Chicago

Pradhan, P, Y. (2005), Outward foreign direct investments from India: Recent trends and patterns, working paper, Gujurat institute of development research

Pradhan, P, Y. (2011), Emerging multinationals: A comparison of Chinese and Indian outward foreign direct investment, International journal of institutions and economics, vol.3, p 113-148

Keers, I., Pennink, B. (2010), The Chinese investment boom in Africa: A substitute for Europe?, South East Asian journal of management, November

Kohnert, D. (2008), EU-African economic relations: Continuing dominance traded for aid? German institute of global and area studies, working paper no. 82

Kragelund, P. (2008) $A$, The return of non-DAC donors to Africa: New prospects for African development? Development policy review, vol. 26, p555-584

Kragelund, P. (2010) B, The potential role of non-traditional donors' aid in Africa, international center for trade and sustainable development, issue paper $\mathrm{nr} .11$

Kragelund, P. (2011) $C$, Back to basics? The rejuvenation of non-traditional donors development cooperation with Africa, development and change, 42, p 585-607

McCormick,D. (2008),China \& India as new Africa donors: The impact of aid on development, Review of African political economy, no. 115, p 73-92

McQueen, M.(2002), The EU's free trade agreements with developing countries: A case of wishful thinking? World economy, September

Nanji, M., Radeva, D. (2009), India and Africa: collaborating on trade and investment for mutual benefit, Trade finance, December, p. 32-38

Rampa, F. Bilal, S. (2011), Emerging economies in Africa and the development effectiveness debate, discussion paper, European center for development policy management

Sauvant, K, P. (2011), New sources of FDI: The BRICS outward FDI from Brazil, Russia, India and China, the journal of world investment and trade

Singh, S, K. (2007), India and West Africa a burgeoning relationship, Africa Asia program Chatman house, April

Thomas. L., Leape, J. (2005), Foreign direct investment in South Africa: the initial impact of the trade, development and cooperation agreement between South Africa and the European Union, Centre for research into economics \& finance in Southern Africa, October

Yusuf, S., Winters, L.A. (2007), Dancing with giants: China, India, and the global economy, World bank and institute of policy studies, 35-66

Voll, K.J. (2010), Africa and India: From long-lasting relations toward future challenges, Foundation for European progressive studies, Brussels, May

Research and Information system for developing countries (2006), India-Brazil-South Africa (IBSA) Economic cooperation: Towards a comprehensive economic partnership. India-Brazil-South Africa Discussion paper 26.

Vidyarthee, K. (2010), India's trade engagements with Africa: A comparison with China, India economy review, August

Zafar, A. (2007), The growing relationship between China and Sub-Saharan Africa: Macroeconomic, trade, investments and aid links, financial times, February. 6

\section{BOOKS}

Berg, A., Drummond, P. (2008), Regional outlook Sub-Saharan Africa. International monetary fund, Africa Department, Washington D.C

Beri, R., Sinha, U, K. (2009), Africa and energy security: Global issues, local responses,

Broadman, H. (2007), Africa's silk road: China and India's new economic frontier, The international bank for reconstruction and development, World bank, Washington D.C 
Pigato, M. (2009), Strengthening China's and India's trade to the Middle East and North Africa, World bank, Washington D.C $1-50$

Moss, T, J. (2007), Making sense of the issues and actors, African Development, Lynne Riener publishers INC, Colorado

Radelet, S. (2010), Emerging Africa: How 17 countries are leading the way, Center for global development, Massachusetts

\section{ELECTRONIC DOCUMENTS}

Africa Business. (2011), Business guide Africa. http://www.africa-business.com/features/bric-in-africa.html. Accessed May. 12, 2011

Africa Union. (2008), India Africa Summit. http://www.africa-union.org/root/au/Conferences/2008/april/IndiaAfrica/India-Africa.htm. Accessed Feb. 15, 2011

British Petroleum. (2010), Statistical energy review.

http://www.bp.com/liveassets/bp_internet/globalbp/globalbp_uk_english/reports_and_publications/statistical_ energy_review_2008/STAGING/local_assets/2010_downloads/oil_section_2010.pdf. Accessed Apr. 21, 2011

Center for strategic and international studies. (2006), Asia monitor: India's energy dilemma.

http://csis.org/files/media/csis/pubs/sam98.pdf. Accessed Jun, 19, 2011

Devex. (2011), The development newswire. http://www.devex.com/en/blogs/the-development-newswire/indiapledges-190m-aid-to-tanzania-s-water-education-sectors . Accessed May. 21, 2011

De wereld morgen. (2010), Olifant volgt staart van de draak India-Afrika.

http://www.dewereldmorgen.be/artikels/2010/04/16/olifant-volgt-de-staart-van-de-draak-india-afrika. Accessed, Feb. 5, 2011

Earth times. (2007), India to provide 900 million in aid to Nigeria.

http://www.earthtimes.org/articles/news/125400.html Accessed Jun. 2, 2011

Economist. (2007), India's economy: India on fire. http://www.economist.com/node/8625681. Accessed May. 9,2011

EU donor Atlas. (2010), EU key trends per country. http://fs3-2010.bbj.it/EURDA_01.aspx?r=Africa\%20\%20South\%20of\%20Sahara. Accessed May. 12, 2011

European Commission. (2007), Directorate for general trade. http://trade.ec.europa.eu/doclib/docs/2007/december/tradoc_137129.pdf. Accessed Apr .13, 2011

European Commission. (2009), Everything-but-arms. http://ec.europa.eu/trade/wider-

agenda/development/generalised-system-of-preferences/everything-but-arms/. Accessed Jun. 12, 2011

European Commission. (2009), Trade development and cooperation agreement.

http://europa.eu/legislation_summaries/development/south_africa/r12201_en.htm. Accessed Jun. 12, 2011

European Commission. (2010), Cotonou agreement.

http://ec.europa.eu/europeaid/where/acp/overview/cotonou-agreement/cotonou_accra_en.htm. Accessed Jun. 12,2011

European Commission. (2010), The ACP regions. http://ec.europa.eu/trade/wider-

agenda/development/economic-partnerships/negotiations-and-agreements/\#sadc. Accessed Jun. 12, 2011

European Commission. (2011), Free trade agreements. http://ec.europa.eu/trade/creatingopportunities/bilateral-relations/free-trade-agreements. Accessed Jun. 12, 2011

Eurostat, (2010), Africa-EU economic indicators: trade and investments. http://epp.eurostat.ec.europa.eu/statistics_explained/index.php/Africa-EU__economic_indicators,_trade_and_investment. Accessed June 2, 2011 
Eurostat. (2010), Foreign direct investment flow s hit by financial crisis.

http://epp.eurostat.ec.europa.eu/cache/ITY_OFFPUB/KS-SF-10-029/EN/KS-SF-10-029-EN.PDF. Accessed Jun. 8, 2011.

Focus Africa. (2011), Country at glance. http://focusafrica.gov.in/Country_at_glance_Nigeria.html

India Nigeria trade. Accessed May. 17, 2011

Forum on China Africa cooperation. (2004), Economic and trade cooperation

http://www.focac.org/eng/zfgx/t463749.htm. Accessed Jun. 8, 2011

Frankfurter Zeitung. 2008. G8. (2006), Debt relief Africa.

http://www.g8.utoronto.ca/evaluations/2005compliance_final/2005-07-g8-f-comp-afdebt.pdf . Accessed Jun 9, 2011

Hindu Business Line. (2010), Africa. http://www.thehindubusinessline.com/todays-paper/tp-

economy/article975604.ece. Accessed Feb. 14, 2011

India department of Commerce. (2006), Trade promotion schemes and programmes.

http://commerce.nic.in/trade/international_tpp.asp?id=3\&trade=i. Accessed Jun. 4, 2011

India ministry of external affairs. (2011), India Africa summit. http://www.mea.gov.in/indiaafricasummit.

Accessed Feb. 15, 2011.

India trade promotion. (2010), View on trade in India. http://www.indiatradepromotion.com . Accessed Jun. 3, 2011

Lesotho ministry of trade. (2011), Why invest in Lesotho. http://www.trade.gov.ls/invest/default.php. Accessed May. 12, 2011

Madote. (2010), Top ten nations of foreign aid recipients. http://www.madote.com/2010/10/top-10-nations-offoreign-aid.html Accessed May. 21, 2011

Mitra. (2010), India drops plan for international development agency. http://www.igovernment.in/site/indiadrops-plan-external-aid-agency-37739. Accessed May, 15, 2011

OECD. (2006), Benchmark report. http://www.oecd.org/dataoecd/10/16/2090148.pdf. Accessed May. 15, 2011

People's daily. (2006), India to invest 6 billion in Nigeria.

http://english.people.com.cn/200605/22/eng20060522_267527.html. Accessed Jun. 9, 2011

Rabobank. (2011), Country report Angola. http://overons.rabobank.com/content/images/Angola-201011_tcm64132056.pdf. Accessed May. 17, 2011

Rabobank. (2011), Country report Kenya. http://overons.rabobank.com/content/images/Kenya-201011_tcm64132057.pdf. Accessed May. 16, 2011

Rabobank. (2011), Country report Nigeria. http://overons.rabobank.com/content/images/Nigeria201102_tcm64-75052.pdf. Accessed May. 16, 2011

United Nations Conference on Trade and Development. (2002), Trends in outward foreign direct investments. http://www.unctad.org/templates/Page.asp?intItemID=3630\&lang=1. Accessed on May. 14, 2011

United Nations Economic Commission for Africa. (2010), statistics http://www.uneca.o

rg/statistics/docs/asyb2010/ADB_Yearbook_2010_web.pdf. Accessed Jun 4, 2011

World Bank. (2011), Country overview.

http://web.worldbank.org/WBSITE/EXTERNAL/COUNTRIES/AFRICAEXT/0,,menuPK:258649 pagePK:158889 piPK:146815 theSitePK:258644,00.html. Accessed May. 15, 201 